\title{
Identifying the Relationship Between Trade and Exchange Rate Volatility*
}

Christian Broda (FRBNY) and John Romalis (Chicago GSB and NBER). First Draft: January 2003. This Draft: February 2004.

\begin{abstract}
We develop a model of international trade in which trade depresses real exchange rate volatility and exchange rate volatility impacts trade in products differently according to their degree of differentiation. In particular, commodities are less affected by exchange rate volatility than more highly differentiated products. These insights allow us to simultaneously identify both channels of causation, thereby structurally addressing one of the main shortcomings of the existing empirical literature on the effects of exchange rate volatility on trade - the failure to correct for reverse causality. Using disaggregate trade data for a large number of countries for the period 1970-1997 we find strong results supporting the prediction that trade dampens exchange rate volatility. We find that once we address the reverse-causality problem, the large effects of exchange rate volatility on trade found in some previous literature are greatly reduced. In particular, the estimated effect of currency unions on trade is reduced from 300 percent to be between 10 and 25 percent.
\end{abstract}

*Thanks are due to Mark Aguiar, Guillermo Calvo, Robert Feenstra, Erik Hurst, Silvana Tenreyro, Shang-Jin Wei, Kei-Mu Yi, and participants at seminars at Chicago GSB, Federal Reserve System Committee Meeting, LACEA Conference 2003, NBER ITI Meeting, Minnesota, RIN Conference 2003, and Wisconsin for helpful suggestions. Any errors are our own. 


\section{Introduction}

A traditional criticism of flexible exchange rate regimes is that flexible rates increase the level of exchange rate uncertainty and thus reduce incentives to trade. ${ }^{1}$ This criticism has generated a large literature that focuses on the impact of exchange rate volatility on trade. However, Mundell's (1961) optimal currency area hypothesis suggests an opposite direction of causality, where trade flows stabilize real exchange rate fluctuations, thus reducing real exchange rate volatility. ${ }^{2}$ These two seminal ideas of international trade imply the existence of a standard identification problem: is the correlation between trade and exchange rate volatility indicative of the effect of volatility on trade or vice versa?

Few theoretical and empirical papers have attempted to answer this question. Most of the existing studies have focused on the effects of exchange rate regimes or volatility on trade by effectively assuming that the exchange rate process is driven by exogenous shocks and is unaffected by other endogenous variables. ${ }^{3}$ By definition this implies that the effect of trade on volatility is assumed inexistent rather than jointly estimated with the effect of volatility on trade. ${ }^{4}$ Figure 1 illustrates that this is not a benign assumption. This figure shows a strong positive relationship between real exchange rate volatility and distance between trading partners. Since distance cannot be affected by volatility, this strong relationship suggests that greater distance between countries significantly increases bilateral exchange rate volatility through the effect of distance on the intensity of commercial relationships such as trade. ${ }^{5}$ Ignoring the causal effect of trade on volatility results in overestimates of the true impact of exchange rate volatility on trade.

We use a model of bilateral trade to structurally estimate the effect on trade of exchange rate volatility and exchange rate regimes such as fixed exchange rates and currency boards. The model highlights the role of trade in determining bilateral real exchange rate volatilities (the source of reverse causality), and the differences in the impact of real exchange rate volatility on trade in different types of goods. Firstly, real exchange rate volatility affects trade in differentiated products but does not affect where a commodity gets sold. Secondly, trade in all products affects real

\footnotetext{
${ }^{1}$ Taussig (1924) was an early advocate of this idea.

${ }^{2}$ Central banks in many developing countries have targeted real effective exchange rates in the past. This implies that even if trade does not act as a automatic stabilizer, policy interventions will reduce bilateral volatility with major trading partners.

${ }^{3}$ Even in the full general equilibrium models of Baccheta and van Wincoop (2001) and Obstfeld and Rogoff (2001) exchange rate volatility is purely determined by exogenous shocks.

${ }^{4}$ The only exceptions are the empirical papers by Frankel and Wei (1996), Persson (2001), Tenreyro and Barro (2002) and Tenreyro (2003). We discuss the identification strategies of these papers in the main text.

${ }^{5}$ This result is related to Engel and Rogers (1996) and Alesina et al. (2002), who examine the importance of distance in the co-movement of price shocks across cities and countries, respectively. It also relates to recent work by Hau (2002) who finds that differences in openness can explain the cross-country variation in the volatility of effective real exchange rates.
} 
exchange rate volatility. These features of the model constitute the main building blocks of our identification strategy. They imply that a component of trade (i.e., commodity trade) is not subject to the simultaneity problem, and can be used to identify how trade affects exchange rate volatility. Once one of the directions of causality is uncovered, we can identify the other, that is, the effect that volatility has on trade in differentiated products.

The intuition behind the main predictions of the model is fairly simple. First, in our model all trade acts as an automatic stabilizer of real exchange rates. To be consistent with our data, we take the real exchange rate between two countries to be the ratio of consumer price levels expressed in a common currency. In equilibrium, proximate countries have more similar consumption baskets than more distant countries. This implies that more proximate countries have lower real exchange rate volatility than more distant countries, consistent with the data presented in Figure 1. This is because a shock that changes the price of a country's good will affect the price of the consumption basket of a neighboring country more than that of a more distant country. In the limit, if baskets are identical, real exchange rates are constant.

Second, in our model exchange rate volatility only affects trade in differentiated products. Commodity products are sold in organized exchanges. Subject to transport costs, buyers and sellers do not care who they buy from or sell to, what they end up paying or receiving is identical regardless of the counterparty. With differentiated products the same is not true. Rauch (1999) argues that the heterogeneity of most manufactured products in both characteristics and quality prevents traders from using organized exchanges for these products. Instead, connections between sellers and buyers are made through a costly search process. This cost can be associated with establishing networks, advertising, and marketing in general. Real-exchange rate volatility that occurs after these costs are sunk will affect the profitability of these connections. Therefore, in contrast to commodity products, trade in differentiated products is affected by exchange rate volatility. ${ }^{6}$

We use disaggregated data to exploit our identification structure and test the predictions of the model. Rauch (1999) provides a categorization of SITC Revision 2 industries according to three possible product types: differentiated, reference priced, and commodity. Bilateral trade data for each SITC industry is available for a large number of developed and developing countries during the period 1970-1997. We calculate several measures of bilateral real exchange rate volatility from monthly real exchange rate series for the same period. We source data on exchange rate regimes from Frankel and Rose (2002), the IMF, Rogoff and Reinhart (2003), and Levy Yeyati and Sturzennegger (2000) (hereafter LYS).

\footnotetext{
${ }^{6}$ The sign of the effect of volatility on trade in differentiated products depends on the degree of risk aversion of the firms that are exporting them. When firms are sufficiently risk averse (loving), relatively more differentiated products will be exported to countries that have low (high) exchange rate volatilities with the exporting country.
} 
The empirical findings of this paper provide support for the view that trade depresses real exchange rate volatility. A trading relationship that is 1 percent of GDP greater than the median trade relationship implies that the volatility of the bilateral real exchange rate associated with the intense trading partner is 12 percent smaller than with the median partner. The empirical findings also support the view that real exchange rate volatility only moderately depresses exports. We find that doubling real exchange rate volatility decreases exports of differentiated products by 2 percent. The reduction from OLS estimates, which suggest an effect over three times larger, is because the model attributes most of the correlation between trade and volatility to the effect that trade has in depressing volatility.

The empirical methodology is suitable for testing the effect of exchange rate regimes on countries' trade performances. While several studies have found large positive effects of fixed regimes on trade (see for example Ghosh et al. (1997) and Frankel and Rose (2002)) they do not control for the reverse-causality problem. However, we observe many fixed regimes pegging their currency to that of countries which are their main trading partners suggesting that reverse causality can be an important problem. ${ }^{7}$ Indeed, we find that the effect of fixed regimes on trade is much smaller when the reverse causation is modeled. In particular, the effect of currency unions is substantially reduced from 300 percent to between 10 and 25 percent when we apply our methodology to Frankel and Rose's data, with very little loss of precision.

This paper departs from the existing literature in several dimensions. First, this paper represents the first attempt to structurally estimate the relationship between trade and exchange rate volatility. Previous attempts to correct for the problem of reverse causality relied on assumptions about appropriate instruments. Frankel and Wei (1996) use the standard deviation of relative money supplies as an instrument for the volatility of exchange rates. Tenreyro and Barro (2002) and Tenreyro (2003) model the formation of exchange rate regimes to derive an instrument for volatility. They get identification by assuming that "bilateral trade between countries $i$ and $j$ depends on gravity variables for countries $i$ and $j$, but not on gravity variables involving third countries, notably the potential anchors," and using the gravity variables with third countries as instruments for bilateral trade. Their IV estimates of the effect of currency unions on trade are substantially larger than OLS estimates. By contrast, in the case of fixed exchange rates Tenreyro finds no effects of fixed exchange rates on trade. But their identification assumption is not supported by standard trade models. In most of these models, trade between countries $i$ and $j$ will greatly depend on the trading opportunities with third countries. This is also an important feature of the model used in this paper.

Persson (2001) addressed the simultaneity problem by modelling selection into currency unions to construct control groups for countries "treated" with a currency

\footnotetext{
${ }^{7}$ The European Monetary System and the Central Franc Zone are just two examples of this behavior.
} 
union. By controlling for this selection bias, he finds that a common currency boosts trade by between 13 and 65 percent. Recent papers that examine the trade effects of the Euro are also relevant. The introduction of the Euro provides an exogenous shift (a "before" and an "after") that can be used to identify the effect of currency unions on trade. Early results using "gravity" regressions suggest very modest trade increases (see for example, Micco et al (2003). But the Euro experiment may not be as clean as it appears. The introduction of the Euro was long anticipated. These papers will need to work hard to separate the trade effects of the common currency from the trade effects of other market integration measures adopted by the European Union in recent years.

Second, we know of no paper that models and estimates the effect of exchange rate volatility on the composition of trade. In previous empirical studies, Bini-Smaghi (1991) and Klein (1990) have attempted to use disaggregate data to test whether uncertainty has different effects for different products. They find that different products are affected differently by volatility but the characteristics of those products that have larger effects are not identified.

Third, we model how trade costs affect real exchange rate volatility. Hau (2002) shows that openness can affect real exchange rate volatility through the share of tradable goods in consumption. In his model, however, this share is exogenously given while in our model differences in consumption baskets are endogenously determined by trading and searching costs. In our model the bilateral pattern of real exchange rate volatility can differ across countries even though the underlying shocks to each country are identical.

Lastly, the focus of most of the theoretical literature is on the role that the invoicing currency plays because prices are set before the exchange rate is observed. Therefore, the invoicing currency determines who bears the exchange rate risk. Note that in this setup uncertainty arises between the time in which prices are set and the time final payment is made, which is usually a short period. ${ }^{8}$ We depart from this tradition and focus on the market entry decision of exporting firms, arguably a decision that involves a longer horizon than the pricing decision. There are no price rigidities in our model.

The paper proceeds as follows. Section 2 derives our model and develops our identification strategy. Section 3 describes our data. Section 4 presents the main results of the paper and the comparisons with the exchange rate regime literature. Section 5 presents robustness checks. Section 6 concludes.

\section{Deriving the Empirical Model}

\section{A. Model Description}

\footnotetext{
${ }^{8}$ Informal evidence suggests that this can take between one and six months.
} 
The model has four countries and two sectors, manufacturing and commodities. The manufacturing sector is an adaptation of the Krugman (1980) model of intraindustry trade driven by scale economies and product differentiation. The adaptation is that to serve an export market manufacturers must incur an additional fixed cost in each period before observing that period's exchange rates. After making the entry decision and observing the exchange rate, the manufacturer can set prices optimally for that period. Manufacturers' assumptions about the distribution of exchange rates will affect the entry decision. Exchange rates are affected by productivity shocks that are external to this model. Commodity producers do not face a fixed cost of entry, they are always ready to sell in a market. The realized price levels affect where commodities are sent; exchange rate volatility has no independent effect on commodity trade. Finally we add 'iceberg' transport costs. The transport costs affect the distribution of exchange rates and affect manufacturers' decisions to export. Detailed assumptions are set out below.

1. There are 4 countries $i=1, . ., 4$ on 2 continents; Country 1 and 2 on one continent and 3 and 4 on the other.

2. Each country has its own currency that can be freely exchanged for that of another. The price of Country i's currency in terms of the currency of Country 1, which we call the dollar, is $s_{i}$.

3. There is one factor of production, Labor, supplied inelastically. Labor earns a factor reward of $w_{i}=1$ unit of local currency. The total labor supply in each country is 1 .

4. Trade is always balanced.

5. All consumers in all countries are assumed to maximize identical constantrelative-risk-aversion preferences in each period over a composite manufactured good $M$ and a composite commodity $C$, with the fraction of income spent on $M$ being $b$ (Equation 1).

$$
U=\frac{1}{a}\left(M^{b} C^{1-b}\right)^{a}
$$

6. Commodity sector. The commodity $C$ is a composite good. Perfectly competitive firms in Country $i$ produce an identical commodity under constant returns to scale, requiring $\theta_{i}$ units of labor to produce 1 unit of the commodity. Each country produces a different commodity. For instance, Country 1 might produce wheat while Country 2 produces copper. $C$ can be interpreted as a sub-utility function that depends on the quantity of each commodity consumed. We choose the CES function with elasticity of substitution between two different commodities being $\sigma_{c}$. Let $q_{i}^{D}$ 
denote the quantity consumed of the commodity produced in Country $i$. $C$ is defined by Equation 2:

$$
C=\left(\sum_{i=1}^{4}\left(q_{i}^{D}\right)^{\frac{\sigma_{c}-1}{\sigma_{c}}}\right)^{\frac{\sigma c}{\sigma_{c}-1}}
$$

7. Monopolistic competition in manufacturing. In manufacturing there are economies of scale in production and firms can costlessly differentiate their products. The output of manufacturing consists of a number of varieties that are imperfect substitutes for one another. The quantity produced of variety $v$ is denoted by $q_{v}^{S}$, the quantity consumed by $q_{v}^{D}$. $V$ is the endogenously determined set of varieties produced. $M$ can be interpreted as a sub-utility function that depends on the quantity of each variety of $M$ consumed. We choose the symmetric CES function with elasticity of substitution $\sigma_{m}>1$ :

$$
M=\left(\int_{v \in V}\left(q_{v}^{D}\right)^{\frac{\sigma_{m}-1}{\sigma_{m}}} d v\right)^{\frac{\sigma_{m}}{\sigma_{m}-1}}, \quad \sigma_{m}>1
$$

All manufacturers must serve their domestic market. Manufactures are produced using labor with a marginal cost $w_{i} \theta_{i}$ and a per-period fixed cost. The fixed cost must be paid before manufacturers observe the exchange rates for the period. Average costs of production decline at all levels of output, although at a decreasing rate. Production technology for a firm in Country $e$ selling $q_{v}$ units in the domestic market is represented by a total cost function $T C$ that is assumed to be identical for all firms selling in their domestic market:

$$
T C_{e}\left(q_{v}^{S}\right)=w_{e}\left(\alpha_{1}+q_{v}^{S} \theta_{e}\right)
$$

Manufacturers enter foreign markets through exports only. ${ }^{9}$ To export to a foreign market, the manufacturer must incur a per-period fixed cost for market development, which must be paid before observing exchange rates for that period. ${ }^{10}$ The manufacturer's cost for market development and procuring $x_{v}$ units for export from country $e$ (exporter) to country $i$ (importer) is represented by the Free On Board (FOB) export cost function $X C$ :

$$
X C_{e i}\left(x_{v}^{S}\right)=w_{e}\left(\alpha_{2}+x_{v}^{S} \theta_{e}\right)
$$

\footnotetext{
${ }^{9}$ If they produce in a foreign country, their cost structure is identical to a domestic firm's.

${ }^{10}$ The critical assumption is not the fixed cost $\alpha_{1}$ for commencing domestic production, but how large the fixed cost $\alpha_{2}$ for entering each export market is relative to $\alpha_{1}$.
} 
8. Costly international trade. There may be a transport cost for international trade. To avoid the need to model a separate transport sector, transport costs are introduced in the convenient but special iceberg form. $\tau_{1 m}$ units of a manufactured good must be shipped for 1 unit to arrive in the country on the same continent, $\tau_{2 m}$ units must be shipped for 1 unit to arrive in a country on a different continent $\left(\tau_{2 m} \geq \tau_{1 m} \geq 1\right)$. The equivalent transport costs for commodities are $\tau_{1 c}$ and $\tau_{2 c}$.

9. Exchange rate movements are driven by shocks to labor productivity $\theta_{i}^{-1} \in$ $(0,1)$.

\section{B. Equilibrium in Commodity Sectors}

In general equilibrium consumers maximize utility, firms maximize profits, all factors are fully employed and trade is balanced. Productivity shocks determine exchange rates $s_{e}$. The equilibrium for commodity sectors is straightforward. Firms always price at marginal cost. For their domestic market, marginal cost in local currency is simply equal to the marginal unit labor requirement, $\theta_{e}$. For export markets marginal cost is higher due to the transport cost. The price, in dollars, of a commodity produced in country $e$ (exporter) and sold in country $i$ (importer) is given by Equation 6:

$$
p_{e i}=\left\{\begin{array}{ccc}
s_{e} \theta_{e} & e=i ; & \text { domestic sales } \\
s_{e} \theta_{e} \tau_{1 c} & e \neq i ; & e, i \text { on same continent } \\
s_{e} \theta_{e} \tau_{2 c} & e \neq i ; & e, i \text { on different continents }
\end{array}\right.
$$

Consumers spend a fixed proportion of their income on commodities. They demand some of each commodity. Income in Country $i$ in dollars is simply $s_{i}$. Maximizing Equation 1 yields the following demand functions in Country $i$ for commodities produced in $e$ :

$$
q_{e i}^{D}=\frac{\left(s_{e} \theta_{e} \tau_{e i c}\right)^{-\sigma}}{\sum_{e^{\prime}}\left(s_{e^{\prime}} \theta_{e^{\prime}} \tau_{e^{\prime} i c}\right)^{1-\sigma}}(1-b) s_{i}
$$

where $\tau_{e i c}=1, \tau_{1 c}$, or $\tau_{2 c}$, according to Model Assumption 9. Note how trade costs involving third countries $e^{\prime}$ directly affect the trade between $e$ and $i$. It is convenient to define the ideal price index for commodities in Country $i, P_{i c}$ :

$$
P_{i c}=\left(\sum_{e}\left(s_{e} \theta_{e} \tau_{e i c}\right)^{1-\sigma_{c}}\right)^{\frac{1}{1-\sigma_{c}}}
$$


Equations 6 through 8 can be solved for log of the value of commodity imports into Country $i$ from Country $e$ :

$$
\ln p_{e i} q_{e i}^{D}=\left(1-\sigma_{c}\right) \ln s_{e} \theta_{e}+\left(1-\sigma_{c}\right) \ln \tau_{e i c}+\ln (1-b) s_{i}-\left(1-\sigma_{c}\right) \ln P_{i c}
$$

We can eliminate Country $i$ specific effects such as its commodity price index $P_{i c}$ and income spent on commodities $(1-b) s_{i}$ by differencing. In particular, the log value of Country $i$ 's imports of commodities from Country $e, \ln C_{e i}$, less the $\log$ value of Country $i$ 's imports of commodities from Country $e^{\prime}$ is:

$$
\ln C_{e i}-\ln C_{e^{\prime} i}=\left(1-\sigma_{c}\right)\left(\ln s_{e} \theta_{e}-\ln s_{e^{\prime}} \theta_{e^{\prime}}\right)+\left(1-\sigma_{c}\right)\left(\ln \tau_{e i c}-\ln \tau_{e^{\prime} i c}\right)
$$

\section{Equilibrium in Manufacturing Sectors}

The equilibrium in manufacturing sectors is more involved. The crucial difference is that some manufacturers may not end up exporting to some or all foreign markets, and that this proportion will depend on the perceived volatility of exchange rates. The properties of the model's demand structure for manufactures have been analyzed in Helpman and Krugman (1985). ${ }^{11}$ Let $p_{e i, v}$ be the price paid by consumers in country $i$, inclusive of transport costs, for a variety $v$ that happens to be produced in country $e$, expressed in dollars. Maximization of Equation 1 yields the following demand functions for variety $v$ in country $i$ :

$$
q_{e i, v}^{D}=\frac{p_{e i, v}^{-\sigma_{m}}}{\int_{v^{\prime} \in V} p_{e i, v^{\prime}}^{1-\sigma_{m}} d v^{\prime}} b s_{i} ; \quad \forall v \in V
$$

A firm's share of industry revenues depends on its own price and on the prices set by all other firms in that industry. It is convenient to define the ideal price index for manufactures in Country $i, P_{i m}$ :

$$
P_{i m}=\left[\int_{v \in V} p_{e i, v}^{1-\sigma_{m}} d v\right]^{\frac{1}{1-\sigma_{m}}}
$$

Each firm produces a different variety of the product. Each country produces different varieties. Consumers demand some of every variety made available to them.

\footnotetext{
${ }^{11}$ See Sections 6.1, 6.2 and 10.4 in particular.
} 
Profit maximizing firms perceive a demand curve that has a constant elasticity, and therefore set price at a constant markup over marginal cost. ${ }^{12}$ An individual firm in country $e$ set a single factory gate dollar price of $\widehat{p}_{e, v}$ :

$$
\widehat{p}_{e, v}=\frac{\sigma_{m}}{\sigma_{m}-1} s_{e} \theta_{e}
$$

For export markets marginal cost is higher due to the transport cost. The consumer price $p_{e i, v}$, in dollars, of a manufactured good $v$ produced in country $e$ and sold in country $i$ is given by Equation 14:

$$
p_{e i, v}=\widehat{p}_{e i, v} \tau_{e i m}
$$

Country $e$ 's products sell in its own domestic market at the factory gate price $\widehat{p}_{e, v}$, but in export markets the transport cost raises the price to $\widehat{p}_{e, v} \tau_{e i m}$. The ideal manufacturing industry price index for Country $i, P_{i m}$, is given in Equation 15 . We assume a symmetric equilibrium if each country faces the same distribution of shocks to government expenditure. Prior to the realization of the exchange rate shock, all countries are alike with $n$ firms manufacturing in each country, and that $n f_{e i}$ manufacturing firms from Country $e$ export to Country $i$. Let $f_{e i}=f_{1}$ if $e$ and $i$ are on the same continent, and $f_{e i}=f_{2}$ if $e$ and $i$ are on different continents. Note that $f_{e i}=1$ if $e=i$ (domestic sales). The free entry conditions for $f_{1}$ and $f_{2}$ are examined below.

$$
P_{i m}=\left[\sum_{e} n f_{e i}\left(\frac{\sigma_{m}}{\sigma_{m}-1} s_{e} \theta_{e} \tau_{e i m}\right)^{1-\sigma_{m}}\right]^{\frac{1}{1-\sigma_{m}}}
$$

Equation 16 gives real profits for sales in Country $i$ for a manufacturer based in Country $e: \frac{1}{\sigma_{m}}$ is the profit margin; $\alpha_{i} s_{e}$ is the fixed market development cost in dollars, where $\alpha_{i}=\alpha_{1}$ if $e=i$ (domestic sales) and $\alpha_{i}=\alpha_{2}$ if $e \neq i$ (export sales); the remainder of the term in brackets are sales revenues in dollars; while $P_{e}=\left(P_{e m}\right)^{b}\left(P_{e c}\right)^{1-b}$ is the ideal price index in Country $e$.

$$
\left[\frac{1}{\sigma_{m}}\left(\frac{\frac{\sigma_{m}}{\sigma_{m}-1} s_{e} \theta_{e} \tau_{e i m}}{P_{i m}}\right)^{1-\sigma_{m}} b s_{i}-\alpha_{i} s_{e}\right] \frac{1}{P_{e}}
$$

\footnotetext{
${ }^{12}$ The demand curve faced by a firm has a constant elasticity if there are an infinite number of varieties.
} 
With free entry, manufacturers establish themselves in each Country $e$ and make decisions to export to each other country $i$ until for each manufacturer:

$$
\underset{I_{e i}}{\operatorname{Max}}\left[E\left(\sum_{i} I_{e i}\left[\frac{1}{\sigma_{m}}\left(\frac{\frac{\sigma_{m}}{\sigma_{m}-1} s_{e} \theta_{e} \tau_{e i m}}{P_{i m}}\right)^{1-\sigma_{m}} b s_{i}-\alpha_{i} s_{e}\right] \frac{1}{P_{e}}\right)^{a}\right]=0
$$

where $I_{e i}$ is an indicator variable that takes a value of 1 if a manufacturer exports from $e$ to $i$ and is 0 otherwise, and $a$ is the parameter governing risk aversion. Profitability in each market is a declining function of the number of domestic firms $n$ and the number of foreign firms $n\left(f_{1}+2 f_{2}\right)$ that export to that market, since the price index $P_{i m}$ declines with entry and because $\sigma_{m}>1$. In general, the proportion of manufacturers that export to nearby markets, $f_{1}$, and the proportion $f_{2}$ that export to distant markets will depend on transport costs, market entry costs, the parameter governing risk aversion, $a$, and the distribution of exchange rates. $f_{2}$ will in general differ from $f_{1}$ directly due to the higher transport cost (which reduces willingness to enter) and indirectly through the impact of transport costs on the distribution of exchange rates.

$f_{1}$ and $f_{2}$ are therefore different functions of expected exchange rate volatility. Let $V_{e}$ be the set of all manufacturing varieties produced in Country e. Equations 11 through 17 determine the log of the value of manufacturing imports into Country $i$ from Country $e$ :

$\ln \int_{v \in V_{e}} p_{e i v} q_{e i v}^{D}=\ln f_{e i}+\ln n+\left(1-\sigma_{m}\right) \ln s_{e} \theta_{e}+\left(1-\sigma_{m}\right) \ln \tau_{e i m}+\ln b s_{i}-\left(1-\sigma_{m}\right) \ln P_{i m}$

We can again employ differencing to eliminate Country $i$ specific effects. Equation 19 gives the $\log$ value of Country $i$ 's manufacturing imports from Country $e, \ln M_{e i}$, less the log value of Country $i$ 's manufacturing imports from Country $e^{\prime}$ :

$\ln M_{e i}-\ln M_{e^{\prime} i}=\ln f_{e i}-\ln f_{e^{\prime} i}+\left(1-\sigma_{m}\right)\left(\ln s_{e} \theta_{e}-\ln s_{e^{\prime}} \theta_{e^{\prime}}\right)+\left(1-\sigma_{m}\right)\left(\ln \tau_{e i m}-\ln \tau_{e^{\prime} i m}\right)$

Equation 19 for manufacturing trade depends on the difference in the proportions $f_{e i}$ and $f_{e^{\prime} i}$ of manufacturers who choose to pay the fixed cost to enter Country $i$ 's market, which will depend on the distribution of exchange rates and attitudes to risk. The first two equations of our empirical specification will come from Equations 10 and 19 , recognizing that $f_{e i}$ and $f_{e^{\prime} i}$ are a function of exchange rate volatility. 


\subsection{Endogenous Exchange Rate Volatility}

In most of the existing theoretical literature the exchange rate process is purely driven by exogenous shocks. The earlier literature relied on a partial equilibrium approach in which the exchange rate was assumed to be an exogenous random variable: see Ethier (1973), Viane and Vries (1992) and Hooper and Kohlhagen (1978). More recently, Obstfeld and Rogoff (1998) and Baccheta and van Wincoop (2000) have focused on general equilibrium models of exchange rate fluctuations. They highlight the importance of having fundamentals, such as monetary, fiscal and productivity shocks, drive exchange rate fluctuations. However, in these models, real exchange rates are unaffected by other endogenous variables, and are purely driven by exogenous shocks.

In our model trade acts as an automatic stabilizer of real exchange rates. The model implies that in equilibrium proximate countries have more similar consumption baskets than more distant countries. More similar consumption baskets, in turn, reduce real exchange rate volatility. The intuition for this result is simple. Since real exchange rates are commonly measured as the ratio of price levels $P_{i}$ across countries (denominated in a common currency), a shock to the price of one country's output shifts the relative price level between itself and more proximate countries less than it shifts the relative price levels between itself and more distant countries. Hau (2002) obtains a similar cross-country prediction using a small open economy model by assuming that the share of tradable goods in preferences vary by country. Our model differs from his in two dimensions. First, Hau assumes different consumption baskets across countries, while in our setup they are endogenously determined by trading and searching costs. Second, in our multi-country framework the bilateral pattern of real exchange rate volatility can differ across countries even though the distribution of underlying shocks to each country are identical.

Figure 2 illustrates the impact that trade costs have on real exchange rate volatility in the model. In particular, it shows the relationship between inter-continental trading costs and the relative real exchange rate volatility between countries that share the same continent and between countries on different continents. We assume that the distribution of productivity shocks hitting each individual country are identical; $\sigma_{m}=$ $\sigma_{c}=5$; intra-continental trading costs $\tau_{1 m}=\tau_{1 c}=1$; inter-continental trading costs are $\tau_{2 m}=\tau_{2 c}=\tau_{2}$; firms are risk neutral; and the fixed cost of entering foreign markets is sufficiently low that manufacturers export to all markets. The figure shows that with $\tau_{2}>1$, volatility with distant countries is larger than with proximate countries. It also shows that when the trading costs between continents increase, the inter-continental bilateral real exchange rate volatility rises relative to the intra-continental volatility. For the empirical section that follows, this means that we face a system of simultaneous equations. OLS regressions of trade on exchange rate volatility will be biased towards finding depressing effects of real exchange rate volatility on trade, because trade itself depresses real exchange rate volatility.

But what does the exchange rate volatility equation look like? Suppose that 
productivity in country $e$ rises. At pre-existing exchange rates there is an incipient trade surplus in country $e$. Every country's demand shifts toward country $e$ 's output because the prices of country $e$ 's products falls. Country $e$ 's exchange rate appreciates. How much it appreciates is negatively related to how substitutable country $e$ 's output is for the output of other countries, which is determined by $\sigma_{c}$ and $\sigma_{m}$. But what happens to real exchange rates? In the Appendix it is shown that the sensitivity of country $i$ 's real exchange rate with country $e$ in response to a small movement in Country $e$ 's exchange rate is given by:

$$
\frac{d \ln \frac{P_{i}}{P_{e}}}{d \ln s_{e}}=\left[\frac{M_{e i}+C_{e i}}{G D P_{i}}\right]-\left[\frac{M_{e e}+C_{e e}}{G D P_{e}}\right],
$$

where $M_{e i}\left(C_{e i}\right)$ is the dollar value of manufactures (commodities) produced in country $e$ and consumed in country $i$. The terms in brackets are simply the dollar value of country $e$ 's goods sold in countries $i$ and $e$ respectively divided by aggregate income in those countries. How much the real exchange rate moves depends on the difference in the importance of country $e$ 's goods in country $i$ 's and country $e$ 's consumption baskets. The more that country e exports to country $i$, the more similar their consumption baskets will look. This is consistent with Figures 2 and 3; the less trade there is between countries, the greater the volatility of their real exchange rate. Trade in both manufactures and commodities is important. Without a closed-form solution, we assume that the way that exports from $e$ to $i$ affect bilateral real exchange rate volatility between $e$ and $i$ is given by:

$$
\ln V_{e i}=\gamma+\beta\left(\ln \left[\frac{M_{e i}+C_{e i}}{G D P_{i}}\right]-\ln \left[\frac{M_{e e}+C_{e e}}{G D P_{e}}\right]\right)
$$

\subsection{Empirical Strategy}

We base our empirical specification in Equations 10, 19 and 21. In order to better assess the identification structure suggested by the model, we first present this system of equations in its most general format. We include importer-exporter and time fixed effects to account for the direct effect of bilateral trade costs, and model the proportion of manufacturers that export to foreign markets, $f_{e i}$, as a simple linear function of expected exchange rate volatility between countries $e$ and $i$. Thus we obtain the following system:

$$
\ln M_{e i t}-\ln M_{e^{\prime} i t}=\gamma_{e i}+\delta_{t}+\alpha_{m}\left(\ln V_{e i t}-\ln V_{e^{\prime} i t}\right)+\theta_{m}\left(\ln s_{e t} \theta_{e t}-\ln s_{e^{\prime} t} \theta_{e^{\prime} t}\right)+\varepsilon_{e e^{\prime} i t}^{m}
$$




$$
\begin{aligned}
\ln C_{e i t}-\ln C_{e^{\prime} i t}= & \gamma_{e i}+\delta_{t}+\alpha_{c}\left(\ln V_{e i t}-\ln V_{e^{\prime} i t}\right)+\theta_{c}\left(\ln s_{e t} \theta_{e t}-\ln s_{e^{\prime} t} \theta_{e^{\prime} t}\right)+\varepsilon_{e e^{\prime} i t}^{c} \\
\ln V_{e i t}-\ln V_{e^{\prime} i t}= & \gamma_{e i}+\delta_{t}+\beta\left(\ln \left[\frac{M_{e i t}+C_{e i t}}{M_{e^{\prime} i t}+C_{e^{\prime} i t}}\right]-\ln \left[\frac{M_{e e t}+C_{e e t}}{G D P_{e t}}\right]+\ln \left[\frac{M_{e^{\prime} e^{\prime}}+C_{e^{\prime} e^{\prime}}}{G D P_{e^{\prime} t}}\right]\right) \\
& +\theta_{v}\left(\ln s_{e t} \theta_{e t}-\ln s_{e^{\prime} t} \theta_{e^{\prime} t}\right)+\varepsilon_{e e^{\prime} i t}^{v}
\end{aligned}
$$

The first identification assumption suggested by the model in the previous section is that $\alpha_{c}=0$. This assumption suggests that commodity trade is unaffected by exchange rate volatility. Producers of commodity products are always ready to export their product, only today's price levels matter for how much they export. The second identification assumption, implicit in Equation 24, suggests that the impact of trade on exchange rate volatility is the same regardless of the product being traded (we relax this assumption later as a robustness check). We also assume that our model is rich enough such that $E\left(\varepsilon^{m} \varepsilon^{v}\right)=E\left(\varepsilon^{c} \varepsilon^{v}\right)=0$. These four assumptions allow us to identify the coefficients of interest, $\left(\alpha_{m}, \beta\right)$ without making any assumption about $E\left(\varepsilon^{m} \varepsilon^{c}\right)$. We estimate the system using GMM, imposing these restrictions. Commodity trade is in effect being used as an instrument for the function of trade in Equation 24; the only way commodity trade affects real exchange rate volatility is through its effect in making consumption bundles more similar. With Equation 24 identified, GMM uses the estimated residual $\widehat{\varepsilon}_{e e^{\prime} i t}^{v}$ as an instrument for $\ln V_{e i t}-\ln V_{e^{\prime} i t}$ in Equation 22. This residual is a shock to real exchange rate volatility that is not caused by trade.

This system is general enough to understand the biases introduced by other identifying procedures. In particular, estimating (22) ignoring the existence of (24) introduces the following simultaneity bias to the estimate of $\alpha_{m}$ :

$$
E \widehat{\alpha}_{m}-\alpha_{m}=\frac{\beta}{1-\alpha_{m} \beta} \frac{\sigma_{\varepsilon^{m}}^{2}}{\sigma_{d \bar{V}}^{2}}
$$

where $d \bar{V}=\bar{V}_{e i t}-\bar{V}_{e^{\prime} i t}$ and $\bar{V}_{e i t}$ is the real exchange rate volatility variable purged of the fixed effects and exogenous variables. In the case where $\beta<0$ and $\alpha<0$, then $|\widehat{\alpha}|>|\alpha|$ which implies that the estimate of the effect of trade on exchange rate volatility overestimates the true effect when the reverse causality channel is assumed away. If in addition the econometrician is lax in controlling for bilateral trade costs, it can easily be shown that the simultaneity bias gets exacerbated by the omitted variables bias. In this situation, adding additional proxies for trade costs may reduce the omitted variables bias, but may have no effect on the simultaneity bias.

We adapt the model to estimate the relationship between exchange rate regimes and trade. The underlying idea is very similar to the exchange rate volatility case. 
Countries are more likely to bind their exchange rate to that of their major trading partners, which may have the effect of promoting trade between those countries. We use the methodology described above to identify how trade affects the exchange rate regime and how that exchange rate regime affects trade. In this case $\ln V_{\text {eit }}$ is replaced by a simple indicator variable indicating the presence of a currency union or a currency board $\left(C U_{e i}\right)$, or a fixed exchange rate $\left(F_{e i t}\right)$. This adaptation is open to the criticism that if the monetary authority is interested in promoting trade and realizes that volatility has no impact on commodity trade, it may seek to peg the exchange rate with large manufacturing-trade partners. This criticism can be addressed by reducing the weight given to commodity trade in equation (24).

\section{Trade and Real Exchange Rate Data.}

Rauch (1999) provides a categorization of SITC Revision 2 industries according to three possible product types: differentiated, reference priced, and commodity. The lack of a reference price distinguishes "differentiated" products from the rest. Those industries with reference prices can be further divided into those whose reference prices are quoted on organized exchanges ("commodities") and those whose reference prices are quoted only in trade publications ("reference priced"). The data consists of annual flows of exports from a given country to different importing countries. For instance, Lead (SITC 685) is listed on an organized exchange and therefore treated as a commodity while Footwear (SITC 851) is not and is treated as a differentiated product. Bilateral trade data for each SITC industry is available for a large number of developed and developing countries during the period 1970-1997. The data consists of annual flows of exports from a given country to different importing countries. Table A1 shows the share of each type of product for different regions and time periods. A summary of the sample used in the estimation is listed in Table A1 in the Appendix.

Another essential part of the estimation is to obtain a measure of exchange rate volatility. We use monthly data on real exchange rate series from IFS to compute standard deviations. We de-trend these series using a Hodrick-Prescott filter and take standard deviations of the filtered data in five year periods. ${ }^{13}$ Table A1 also shows the descriptive statistics of these series. The additional data needed for the main specifications are taken from the World Development Indicators, except for export prices $s_{e} \theta_{e}$, which are computed using detailed unit export price data in US trade statistics described in Feenstra et al. (1997 and 2002) after extracting product-byyear fixed effects.

We source data on currency unions and currency boards from Frankel and Rose (2002). The paper also uses data on other fixed exchange rate regimes. The basic ref-

\footnotetext{
${ }^{13}$ We identify the trend from the monthly log real exchange rate data using a smoothing parameter of $1,000,000$. Our volatility measure is the standard deviation of the detrended series over the previous 5 years. For robustness checks, the detrended series is further decomposed into short-term volatility and medium-term volatility, by smoothing these deviations using a smoothing parameter of 400 .
} 
erence for classification of exchange rate regimes is the International Monetary Fund's Annual Report on Exchange Arrangements and Exchange Restrictions (AREAER). ${ }^{14}$ This classification is a de jure classification that is based on the publicly stated commitment of the authorities in the country in question. The IMF report captures the notion of a formal commitment to a regime, but fails to capture whether the actual policies were consistent with the stated commitment. Since we mainly use bilateral data in the paper, we use the currency to which a country is pegged to create a fixed exchange rate regime dummy that takes the value of one if one country's currency is pegged to the other country's currency or if two countries are pegged to the same currency. While a de jure classification like the IMF's captures the formal commitment to a regime it fails to capture whether the actual policies were consistent with this commitment. For instance, de jure pegs can pursue policies inconsistent with their stated regime and require frequent changes in the nominal exchange rate, making the degree of commitment embedded in the peg in fact similar to a float. The problems that arise from a pure de jure classification have prompted researchers to use different criteria to classify regimes. Reinhart and Rogoff (2002) classify exchange rate regimes using information about the existence of parallel markets combined with the actual exchange rate behavior in those markets. Levy Yeyati and Sturzennegger (2000) analyze data on volatility of reserves and actual exchange rates. A similar bilateral fixed exchange rate dummy is constructed from Reinhart and Rogoff and Levy Yeyati and Sturzennegger database. We source data on currency unions and currency boards from Frankel and Rose (2002).

\section{Results}

The main results of the paper are reported in Tables 1-3. Table 1's first two columns present OLS estimates of Equations 22 and 24. A 10 percent increase in volatility depresses differentiated product trade by 0.7 percent, while a 10 percent increase in trade reduces exchange rate volatility by 0.3 percent. The next two columns present GMM estimates of Equations 22 and 24. The OLS estimate of the effect of volatility on trade is reduced by 70 percent. This reduction is because the model attributes much of the correlation between trade and volatility to the effect that trade has in depressing volatility. A 10 percent increase in the intensity of a bilateral trading relationship reduces the volatility of the associated exchange rate by 0.3 percent. Although the estimate is statistically significant, the magnitude of the effect does not at first appear to be that large. It must be remembered, however, that the typical bilateral trading relationship is very small (the median was under $\$ 8$ million in 1997 , whereas the median GDP is $\$ 32$ billion), while the typical real exchange rate is quite volatile (typically 11 percent from its trend). A trading relationship that is 1 percent of GDP greater than the median trade relationship implies that the volatility of the bilateral real exchange rate associated with the intense trading partner is 12 percent

\footnotetext{
${ }^{14}$ The AREAER classification consists of nine categories, broadly grouped into pegs, arrangements with limited flexibility, and "more flexible arrangements", which include managed and pure floats. This description is based on the AREAER (1996).
} 
smaller than with the median partner. The estimated effect of trade on exchange rate volatility in Table 1, columns $5-8$ is barely changed by the addition of more explanatory variables that often appear in "gravity" models of trade, though the estimated effect of volatility on trade declines.

Table 2 presents estimates from the adaptation of our identification strategy to estimating the effect of currency unions and currency boards on trade. In our sample there are very few instances of a change in currency union or currency board status, so we drop the fixed effects for each importer-exporter relationship and instead include exporter fixed effects and importer fixed effects. The OLS result is again presented in column 1, with the typically large estimate that a currency union increases trade by 250 percent. Columns 2-3 present the GMM estimates. We find that controlling for reverse causality reduces the estimate of the currency union effect to 25 percent; the estimate is one tenth the size of the OLS estimate and just as precise. Almost all of the correlation between trade and the presence of a currency union or a currency board is attributed to the fact that countries are much more likely to adopt the exchange rate of a major trading partner. The addition of explanatory variables that are often used to explain trade in the presence of currency unions does not change the basic story. The OLS estimates are always above 50 percent, the GMM estimates are always small, ranging between 10 and 25 percent, with very little loss in precision relative to their OLS counterparts. The OLS estimates are usually outside 95 percent confidence intervals for the GMM estimates.

Table 3 presents estimates from the adaptation of our identification strategy to estimating the effect of fixed exchange rates on trade. The fact that many countries have changed their exchange rate regime allows us to reintroduce fixed effects for every importer-exporter relationship. The coefficient on the fixed exchange rate variable is only identified because countries have changed their exchange rate regime. All estimates, be they OLS or GMM, suggest only modest effects of fixed exchange rates on trade. The GMM estimates for the two de facto measures of exchange rate regime both suggest that a fixed exchange rate regime increases differentiated product trade by 6 percent.

\subsection{Robustness Checks}

We check the robustness of our results to a number of changes to our empirical model. Table 4 reports sensitivity of our results to alternative measures of exchange rate volatility. We construct three measures to capture volatility at different frequencies by adjusting the smoothing parameters used in the Hodrick-Prescott filters. The data is filtered to isolate very low-frequency movements that we term "long-run" volatility, very high-frequency movements that we term "short-run" volatility, and all-other movements that we term "medium-run" volatility. The estimates based on short-run volatility are higher than the other estimates. Trade is both more sensitive to short-run volatility and has a greater effect in dampening short-run volatility. 
Table 5 performs our basic regression for different regions. In particular we are interested if our results depend on whether the exporting country is developed or developing. All of the depressing effect of volatility on trade comes from developing country exporters. Developed country exporters are not adversely affected by exchange rate volatility. This suggests that developing country exporters are more risk-averse or are less able to hedge the real-exchange rate risk. For both groups of exporters, trade depresses the volatility of the exchange rate.

Table 6 reports the effect of adding information on capital controls and capital flows to each equation. Gross private capital flows sourced from the World Development Indicators is the sum of gross private capital flows as a percentage of GDP for the exporting and the importing country. Capital control data sourced from the IMF's AREAER is the sum of the dummy variables indicating the presence or absence of capital controls in the exporting and importing countries. The results change only slightly.

Figures 4 to 7 illustrate the effect of changing the relative contribution of commodity trade in reducing real exchange rate volatility or in affecting the likelihood of entering into a currency union. This is done by introducing a parameter $\beta_{c}$ to equation 21 describing how trade affects volatility and the equivalent equations describing the formation of exchange rate regimes:

$$
\ln V_{e i}=\gamma+\beta\left(\ln \left[\frac{M_{e i}+\beta_{c} C_{e i}}{G D P_{i}}\right]-\ln \left[\frac{M_{e e}+\beta_{c} C_{e e}}{G D P_{e}}\right]\right)
$$

This new parameter has to be imposed since the model is otherwise unidentified. As this parameter is reduced from the value of 1 used in all prior regressions, the model attributes even more of the correlation between trade and volatility or between trade and the presence of a currency union to the effect that trade has in depressing volatility or leading to a currency union. Exchange rate volatility and currency unions appear to have little impact on trade.

\section{Conclusion}

Most of the studies of the effect of exchange rate volatility on trade assume that the volume of trade has no impact on exchange rate volatility, thus assuming away a simultaneity problem. We present evidence that this problem is severe. We develop a model in which both directions of causality are considered and that allows us to structurally identify the impact of exchange rate volatility on trade. We exploit our identification structure by using disaggregate product trade data for a large number of countries for the period 1970-1997. We find that deeper bilateral trading relations dampen real exchange rate volatility and are much more likely to lead to a currency union. In fact, our empirical model attributes most of the correlation between trade and volatility to the effect that trade has in depressing volatility. 
The paper finds some evidence that real exchange rate volatility depresses trade in differentiated goods. The size of the effect is fairly small once we control for the reverse causality problem. A doubling of real exchange rate volatility decreases trade in differentiated products by about 2 percent. A fixed exchange rate boosts differentiated product trade by about 6 percent. Finally, currency unions enhance trade by $10-25$ percent rather than the 300 percent estimates previously obtained.

\section{Appendix}

Derivation of equation 20. The $\log$ of the price index for country $i$ is:

$$
\ln P_{i}=\left[b \ln P_{i m}+(1-b) \ln P_{i c}\right],
$$

where $P_{i m}$ is defined in equation 15 and $P_{i c}$ is defined in equation 8. Differentiating:

$$
\frac{d \ln P_{i}}{d \ln s_{e}}=s_{e}\left[\frac{b}{P_{i m}} \frac{d P_{i m}}{d s_{e}}+\frac{(1-b)}{P_{i c}} \frac{d P_{i c}}{d s_{e}}\right] .
$$

Substituting out $\frac{d P_{i m}}{d s_{e}}$ and $\frac{d P_{i c}}{d s_{e}}$ :

$$
\frac{d \ln P_{i}}{d \ln s_{e}}=s_{e}\left[\frac{b}{P_{i m}} P_{i m}^{\sigma_{m}} n f_{e i}\left(\frac{\sigma_{m}}{\sigma_{m}-1} s_{e} \theta_{e} \tau_{e i m}\right)^{1-\sigma_{m}} s_{e}^{-1}+\frac{(1-b)}{P_{i c}} P_{i c}^{\sigma_{c}} \tau_{e i c}^{1-\sigma_{c}} s_{e}^{-\sigma_{c}}\right] .
$$

Substituting using equations 6 and 14:

$$
\frac{d \ln P_{i}}{d \ln s_{e}}=b n f_{e i} \frac{p_{e i, v}^{1-\sigma_{m}}}{P_{i m}^{1-\sigma_{m}}}+(1-b) \frac{p_{e i}^{1-\sigma_{c}}}{P_{i c}^{1-\sigma_{c}}} .
$$

The first term on the right side of equation 30 is the proportion of Country $i$ 's income spent on manufactured goods produced in Country $e$, while the second term is the proportion spent on commodities from Country $e$. For small shocks to $s_{e}$, the price index in country $i$ changes in line with the share of country $e$ 's goods in Country $i$ 's consumption basket. Equation 20 follows from our definition of the real exchange rate as the ratio of two price indexes. 


\section{References}

[1] Alesina, A., R. Barro and S. Tenreyro (2002), "Optimal Currency Areas," NBER Macroeconomic Annual.

[2] Baccheta, P. and E. van Wincoop (2000) "Does Exchange Rate Stability Increase Trade and Welfare?" American Economic Review, 90(5), pp.1093-1109.

[3] Tenreyro, S. and R. Barro (2002), "Economic Effects of Currency Unions", mimeo, Federal Reserve Bank of Boston and Harvard University.

[4] Bini-Smaghi, Lorenzo (1991). "Exchange Rate Variability and Trade: Why is it so Difficult to find any Empirical Relationship?" Applied Economics, 23, pp. 927-936.

[5] Chowdhury, Abdur R. (1993). "Does Exchange Rate Volatility Depress Trade Flows? Evidence from Error-Correction Models". The Review of Economics and Statistics, 700-706.

[6] De Nardis S. and C. Vicarelli (2003), "The Impact of the Euro on Trade: The (Early) Effect is Not So Large", ENEPRI Working Paper No. 17.

[7] Dell'Ariccia, Giovanni (1998). "Exchange Rate Fluctuations and Trade Flows: Evidence from the European Union", IMF Working Paper 98/107.

[8] Engel, Charles and John H. Rogers, "How Wide Is the Border?", American Economic Review, Vol. 86(5), pp. 1112-1125.

[9] Frankel, Jeffrey A and Andrew Rose (2002), "An Estimate of the Effect of Currency Unions on Trade and Growth", Quarterly Journal of Economics, 117(2), pp.437-466.

[10] Frankel, Jeffrey A. and Wei, Shang-Jin (1993). "Trade Blocs and Currency Blocs". NBER Working Paper No. 4335.

[11] Gagnon, Joseph E . (1993), "Exchange Rate Variability and the Level of International Trade", Journal of International Economics, 34, pp. 269-287.

[12] Ghosh, A. R., Gulde, A-M.,Ostry, J.,Wolf, H. (1997), "Does the nominal exchange rate matter?" NBER Working Paper No. 5874. National Bureau of Economic Research, Cambridge, MA.

[13] Hau, Harold (2002), "Real Exchange Rate Volatility and Economic Openness: Theory and Evidence", Journal of Money, Credit and Banking, Vol. 34(3), 611630 .

[14] Helpman E., and P. Krugman (1985). Market Structure and Foreign Trade, MIT Press, Cambridge.

[15] Hooper, Peter and Steven Kohlhagen (1978), "The Effect of Exchange Rate Uncertainty on the Prices and Volume of International Trade", Journal of International Economics, Volume 8, pp. 483-511.

[16] Hummels, David (2001), "Toward a Geography of Trade Costs", mimeo, Purdue University, September 2001.

[17] Koray, Faik and Lastrapes, William D. (1989). "Real Exchange Rate Volatility and U.S. Bilateral Trade: A VAR Approach", The Review of Economics and Statistics, 71(4), pp. 708-727.

[18] Krugman P. (1980). "Scale Economies, Product Differentiation, and the Pattern 
of Trade", American Economic Review, 70(5), pp.950-959.

[19] McKenzie, Michael D. (1999). "The Impact of Exchange Rate Volatility on International Flows", Journal of Economic Surveys, 13(1), pp. 71-106.

[20] Micco, Alejandro, Ernesto Stein and Guillermo Ordoñez (2003), "The currency union effect on trade: early evidence from EMU", Economic Policy, Volume 18(37), pp.317-356.

[21] Mundell, Robert A. (1961), "A Theory of Optimal Currency Areas", American Economic Review, Volume 51(4) pp.657-665.

[22] Persson, Torsten (2001), "Currency Unions and Trade: How Large is the Treatment Effect?", Economic Policy, Volume 16(33), pp.433-448.

[23] Rauch, James E. (1999), "Networks versus Markets in International Trade", Journal of International Economics, 48, pp. 7-35.

[24] Taussig, Frank W. (1924), Principles of Economics, Volume 1, Macmillian.

[25] Tenreyro S. (2003), "On the Trade Impact of Nominal Exchange Rate Volatility", mimeo, Federal Reserve Bank of Boston.

[26] Viaene, J.M. and C.G de Vries (1992), "International trade and exchaneg rate volatility", European Economic Review, 36, 1311-21. 

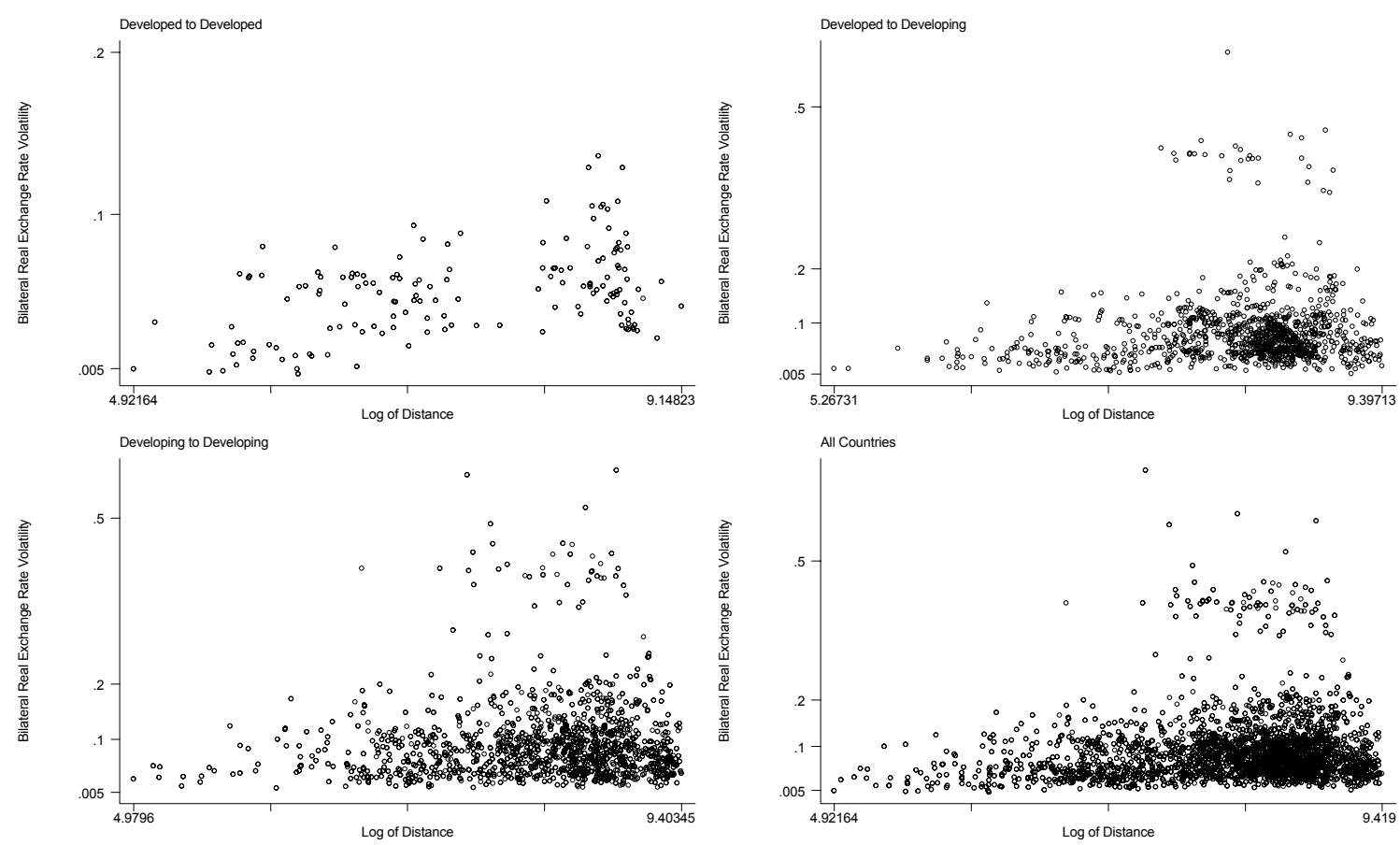

Exchange Rate Volatility and Distance between Countries in 1997 


\section{Difference between Inter-Continental and Intra-Continental Real Exchange Rate Volatility}

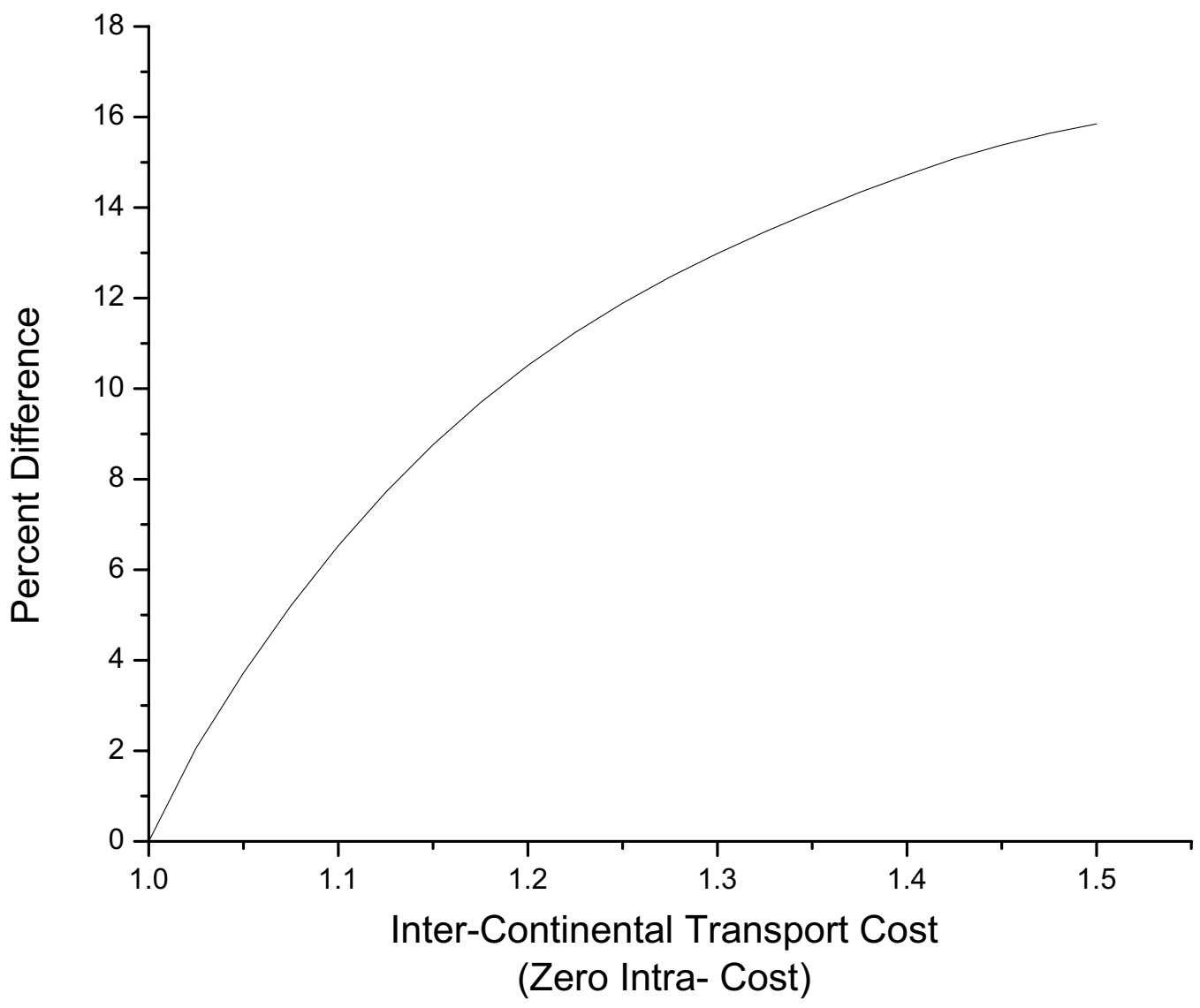

Difference between Inter-Continental and Intra-Continental Trade

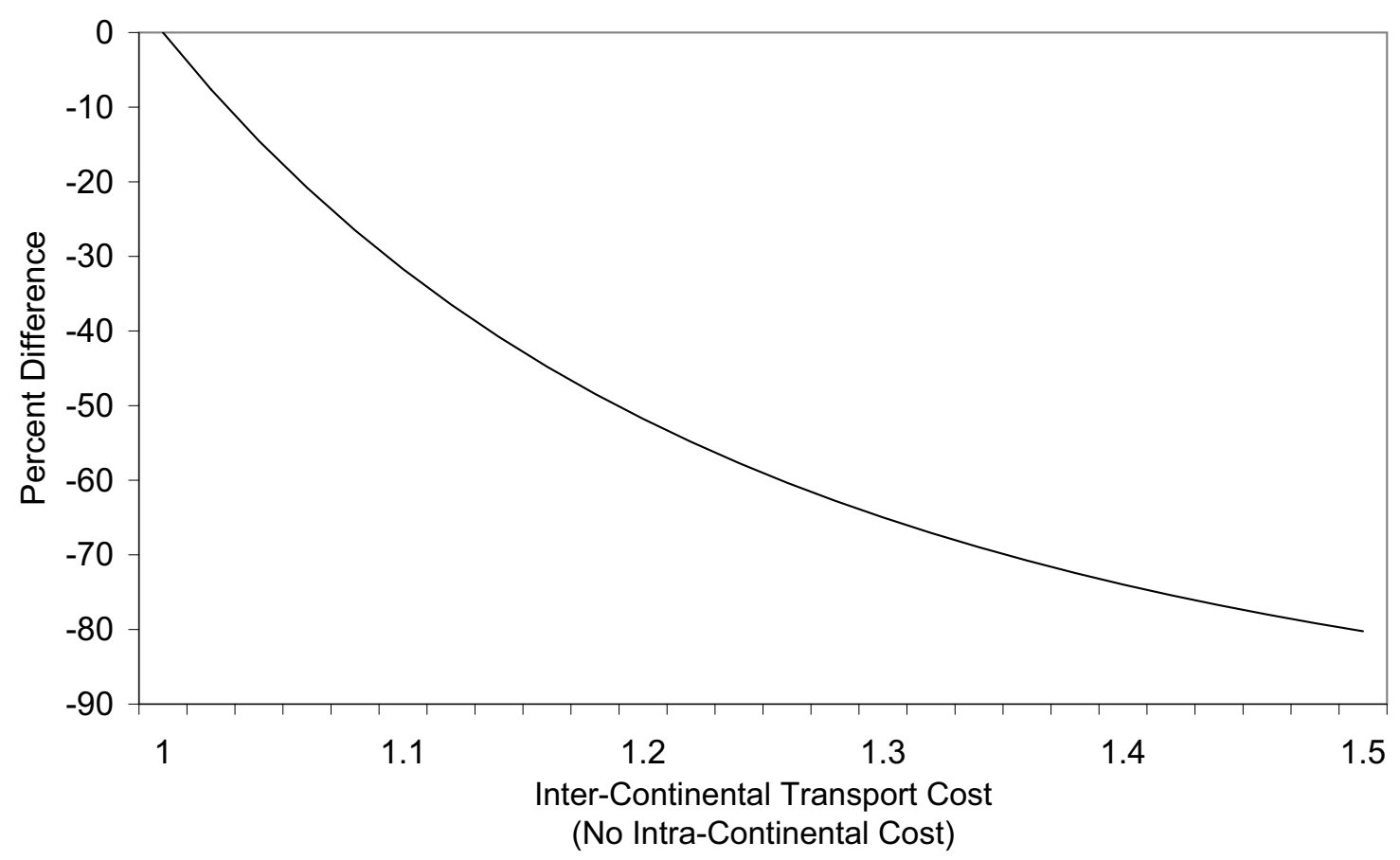


Figure 4: Exchange Rate Volatility and Trade

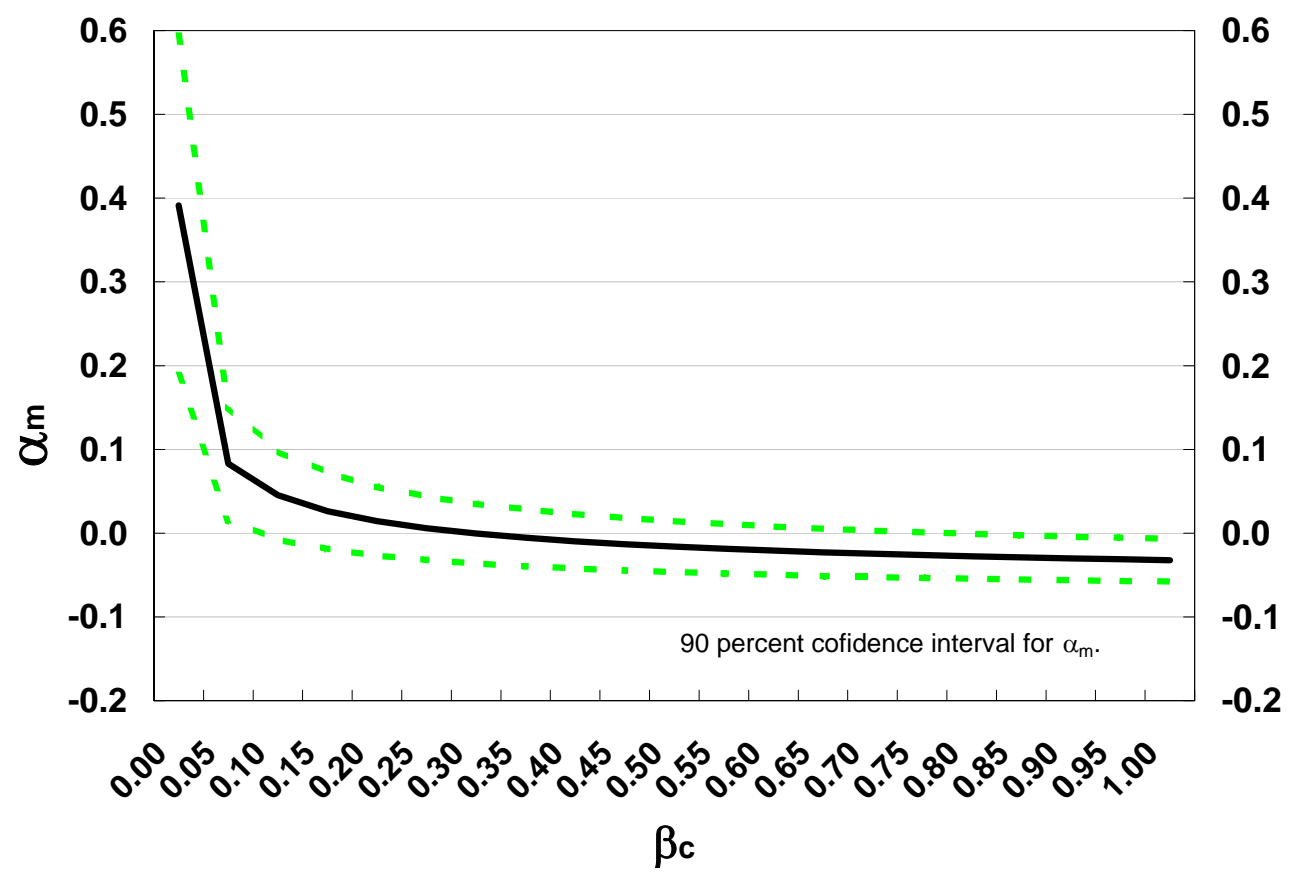

Figure 5: Trade and Exchange Rate Volatility

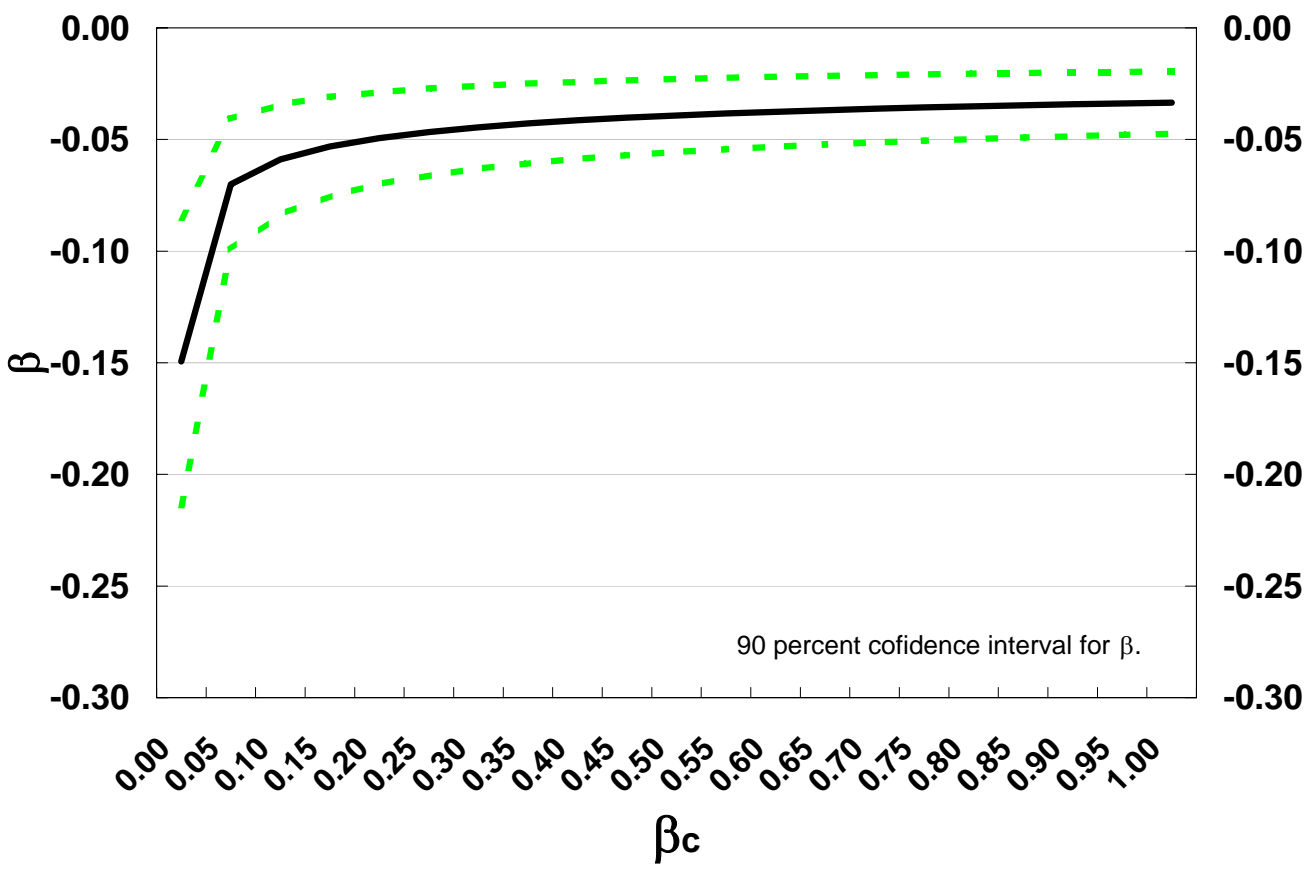


Figure 6: Currency Unions and Trade

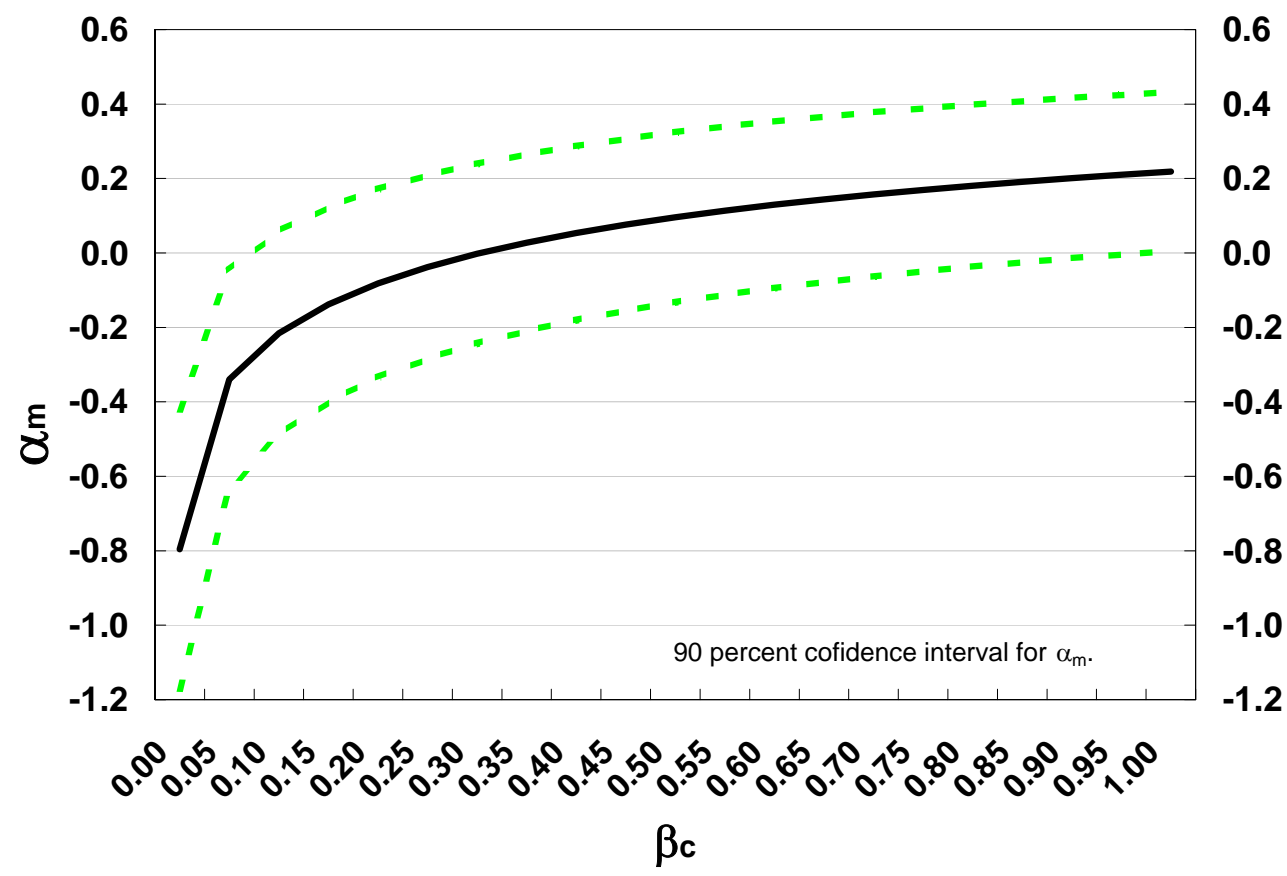

Figure 7: Trade and Currency Unions

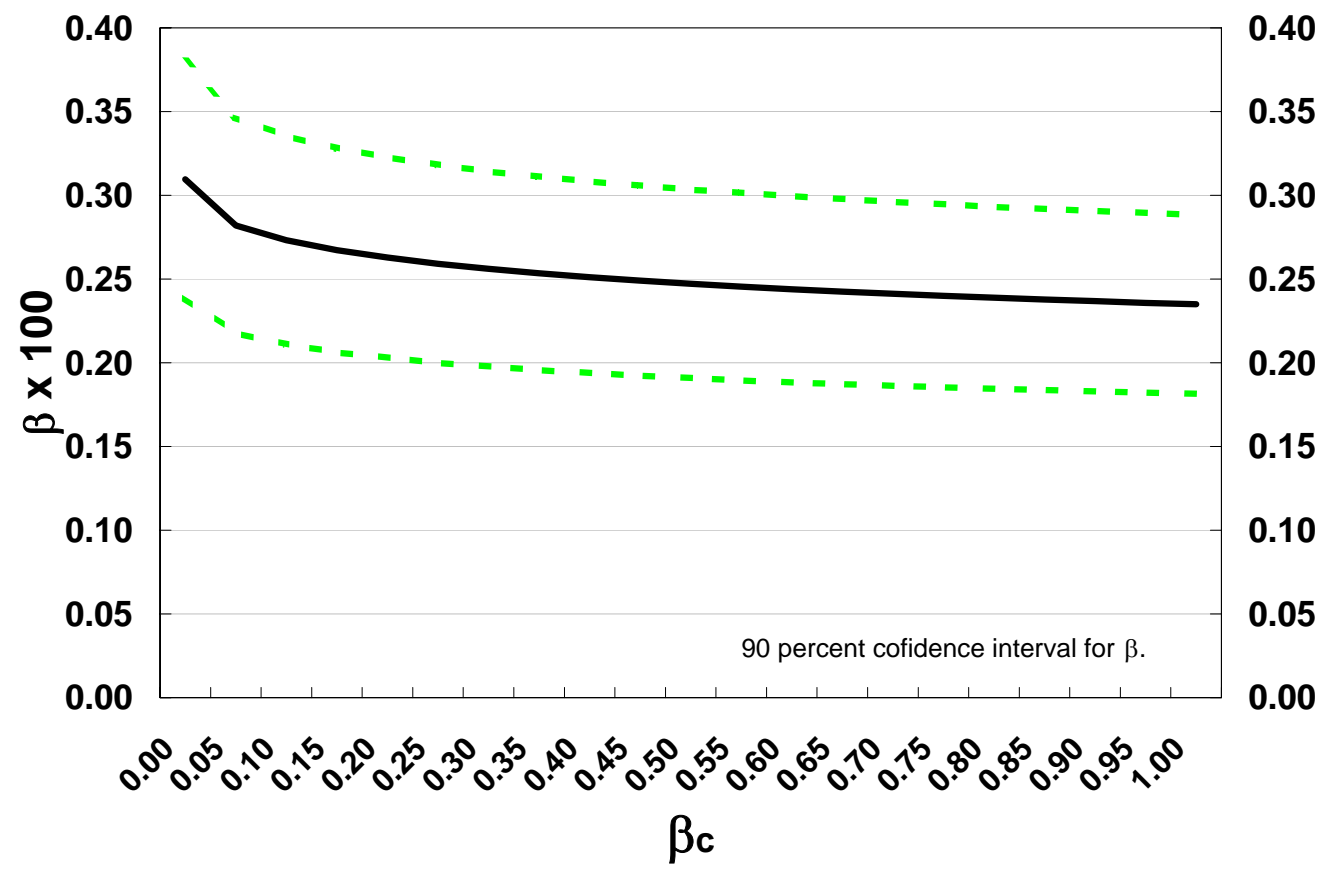


TABLE A1: DESCRIPTIVE STATISTICS

\begin{tabular}{|c|c|c|c|c|c|c|c|c|}
\hline \multirow[t]{2}{*}{ EXPORTER FROM: } & Number of Pairs & $\begin{array}{c}\text { Share of } \\
\text { Exports in } \\
\text { Differentiated } \\
\text { Products }\end{array}$ & $\begin{array}{c}\text { Share of } \\
\text { Exports in } \\
\text { Reference } \\
\text { Products }\end{array}$ & $\begin{array}{l}\text { Share of } \\
\text { Exports in } \\
\text { Commodity } \\
\text { Products }\end{array}$ & $\begin{array}{c}\text { Real Exchange } \\
\text { Rate Volatility } \\
\text { (Medium-Term) }\end{array}$ & $\begin{array}{l}\text { Real Exchange } \\
\text { Rate Volatility } \\
\text { (Short-Term) }\end{array}$ & $\begin{array}{l}\text { IMF Fixed Exchange } \\
\text { Rate Regime Pairs } \\
\text { (1) }\end{array}$ & $\begin{array}{c}\text { Rogoff-Reinhart Fixed } \\
\text { Exchange Rate Regime } \\
\text { Pairs (1) }\end{array}$ \\
\hline & \multicolumn{8}{|c|}{1970 s } \\
\hline AFRICA & 4260 & 0.17 & 0.17 & 0.66 & $7.0 \%$ & $4.6 \%$ & $11.7 \%$ & $3.7 \%$ \\
\hline N.AMERICA & 1191 & 0.59 & 0.20 & 0.21 & $6.1 \%$ & $3.5 \%$ & $0.4 \%$ & $0.3 \%$ \\
\hline C.AMERICA and S.AMERICA & 6977 & 0.11 & 0.15 & 0.73 & $8.1 \%$ & $6.0 \%$ & $20.5 \%$ & $9.7 \%$ \\
\hline ASIA & 4921 & 0.60 & 0.17 & 0.23 & $7.6 \%$ & $4.6 \%$ & $14.4 \%$ & $3.6 \%$ \\
\hline EUROPE & 9081 & 0.65 & 0.24 & 0.12 & $5.7 \%$ & $3.8 \%$ & $3.5 \%$ & $6.1 \%$ \\
\hline \multirow[t]{2}{*}{ ALL } & 26430 & 0.58 & 0.21 & 0.21 & $6.9 \%$ & $4.6 \%$ & $11.6 \%$ & $5.9 \%$ \\
\hline & \multicolumn{8}{|c|}{$1980 \mathrm{~s}$} \\
\hline AFRICA & 5332 & 0.17 & 0.18 & 0.66 & $13.6 \%$ & $7.0 \%$ & $3.7 \%$ & $1.8 \%$ \\
\hline N.AMERICA & 1341 & 0.63 & 0.20 & 0.17 & $10.1 \%$ & $4.8 \%$ & $0.0 \%$ & $0.0 \%$ \\
\hline C.AMERICA and S.AMERICA & 8327 & 0.20 & 0.17 & 0.63 & $15.2 \%$ & $8.2 \%$ & $10.4 \%$ & $1.2 \%$ \\
\hline ASIA & 7085 & 0.73 & 0.11 & 0.17 & $10.2 \%$ & $5.0 \%$ & $2.5 \%$ & $0.1 \%$ \\
\hline EUROPE & 10820 & 0.66 & 0.21 & 0.13 & $10.8 \%$ & $5.1 \%$ & $3.5 \%$ & $0.6 \%$ \\
\hline \multirow[t]{2}{*}{ ALL } & 32905 & 0.62 & 0.19 & 0.19 & $12.2 \%$ & $6.2 \%$ & $4.9 \%$ & $0.8 \%$ \\
\hline & \multicolumn{8}{|c|}{ 1990s } \\
\hline AFRICA & 7514 & 0.24 & 0.23 & 0.53 & $11.1 \%$ & $7.6 \%$ & $2.8 \%$ & $1.1 \%$ \\
\hline N.AMERICA & 1346 & 0.70 & 0.18 & 0.12 & $8.1 \%$ & $5.1 \%$ & $0.0 \%$ & $0.0 \%$ \\
\hline C.AMERICA and S.AMERICA & 9143 & 0.41 & 0.20 & 0.39 & $11.8 \%$ & $8.0 \%$ & $1.4 \%$ & $0.2 \%$ \\
\hline ASIA & 8346 & 0.76 & 0.10 & 0.14 & $8.5 \%$ & $5.2 \%$ & $1.0 \%$ & $0.4 \%$ \\
\hline EUROPE & 12197 & 0.71 & 0.20 & 0.09 & $8.8 \%$ & $5.7 \%$ & $1.1 \%$ & $1.4 \%$ \\
\hline ALL & 38546 & 0.69 & 0.17 & 0.13 & $9.8 \%$ & $6.5 \%$ & $1.4 \%$ & $0.8 \%$ \\
\hline
\end{tabular}

Notes: Pairs are included only if real exchange rate volatility data is available. For Exchange Rate Regimes not all number of pairs have data. 
Table 1 : Exchange Rate Volatility and Trade

Left Hand Side Variable

\begin{tabular}{|c|c|c|c|c|c|c|c|c|}
\hline $\begin{array}{l}\text { Model } \\
\text { Estimation Technique }\end{array}$ & $\begin{array}{c}\text { Log } \\
\text { Differentiated } \\
\text { Product Trade } \\
\text { (1) } \\
\text { OLS }\end{array}$ & $\begin{array}{c}\text { Log Real } \\
\text { Exchange } \\
\text { Rate Volatility } \\
(1) \\
\text { OLS } \\
\end{array}$ & $\begin{array}{c}\text { Log } \\
\text { Differentiated } \\
\text { Product Trade } \\
\text { (1) } \\
\text { GMM }\end{array}$ & $\begin{array}{c}\text { Log Real } \\
\text { Exchange } \\
\text { Rate Volatility } \\
(1) \\
\text { GMM }\end{array}$ & $\begin{array}{c}\text { Log } \\
\text { Differentiated } \\
\text { Product Trade } \\
\text { (2) } \\
\text { OLS }\end{array}$ & $\begin{array}{c}\text { Log Real } \\
\text { Exchange } \\
\text { Rate Volatility } \\
(2) \\
\text { OLS }\end{array}$ & $\begin{array}{c}\text { Log } \\
\text { Differentiated } \\
\text { Product Trade } \\
\text { (2) } \\
\text { GMM }\end{array}$ & $\begin{array}{c}\text { Log Real } \\
\text { Exchange } \\
\text { Rate Volatility } \\
(2) \\
\text { GMM }\end{array}$ \\
\hline \multicolumn{9}{|l|}{ Right Hand Side Variable } \\
\hline Log Real Exchange Rate Volatility & $\begin{array}{c}-0.077 \\
(0.012)\end{array}$ & & $\begin{array}{c}-0.032 \\
(0.015)\end{array}$ & & $\begin{array}{c}-0.059 \\
(0.012)\end{array}$ & & $\begin{array}{c}-0.015 \\
(0.015)\end{array}$ & \\
\hline Log Total Trade & & $\begin{array}{c}-0.034 \\
(0.005)\end{array}$ & & $\begin{array}{c}-0.033 \\
(0.008)\end{array}$ & & $\begin{array}{c}-0.022 \\
(0.005)\end{array}$ & & $\begin{array}{c}-0.033 \\
(0.008)\end{array}$ \\
\hline Log Export Price Level & $\begin{array}{c}-0.595 \\
(0.056)\end{array}$ & $\begin{array}{c}-0.165 \\
(0.026)\end{array}$ & $\begin{array}{c}-0.588 \\
(0.056)\end{array}$ & $\begin{array}{c}-0.165 \\
(0.026)\end{array}$ & $\begin{array}{c}-0.699 \\
(0.064)\end{array}$ & $\begin{array}{c}0.041 \\
(0.025)\end{array}$ & $\begin{array}{c}-0.701 \\
(0.064)\end{array}$ & $\begin{array}{c}0.038 \\
(0.025)\end{array}$ \\
\hline Log Product Real GDP & & & & & $X$ & $X$ & $X$ & $X$ \\
\hline Log Product Real GDP/capita & & & & & $\mathrm{X}$ & $x$ & $x$ & $\mathrm{X}$ \\
\hline Log Exporters' Real GDP & & & & & $x$ & $x$ & $\mathrm{X}$ & $x$ \\
\hline Log Exporters' real GDP/capita & & & & & $x$ & $x$ & $x$ & $x$ \\
\hline Importer-Exporter Fixed Effects & $X$ & $\mathrm{X}$ & $x$ & $X$ & $x$ & $x$ & $x$ & $x$ \\
\hline Year Fixed Effects & $x$ & $x$ & $x$ & $x$ & $x$ & $x$ & $\mathrm{x}$ & $x$ \\
\hline Observations & 47521 & 47521 & 47521 & 47521 & 47521 & 47521 & 47521 & 47521 \\
\hline
\end{tabular}

Notes: Each variable has been differenced as follows: From log differentiated product imports of country I from country E we have subtracted log differentiated product imports of country I from the US. The reason, derived in the model, is to eliminate country I specific effects. All variables are equivalently differenced. Standard errors corrected for heteroscedasticity and autocorrelation are reported in parenthesis. 
Table 2 : Currency Unions, Currency Boards and Trade

\begin{tabular}{|c|c|c|c|c|c|c|c|c|c|}
\hline \multirow[b]{2}{*}{$\begin{array}{c}\text { Model } \\
\text { Estimation Technique }\end{array}$} & \multirow[b]{2}{*}{$\begin{array}{c}\text { Log } \\
\text { Differentiated } \\
\text { Product Trade } \\
\text { (1) } \\
\text { OLS }\end{array}$} & \multirow[b]{2}{*}{$\begin{array}{c}\text { Log } \\
\text { Differentiated } \\
\text { Product Trade } \\
(1) \\
\text { GMM }\end{array}$} & \multicolumn{4}{|c|}{ Left Hand Side Variable } & \multirow[b]{2}{*}{$\begin{array}{c}\text { Log } \\
\text { Differentiated } \\
\text { Product Trade } \\
\text { (3) } \\
\text { OLS } \\
\end{array}$} & \multirow[b]{2}{*}{$\begin{array}{c}\text { Log } \\
\text { Differentiated } \\
\text { Product Trade } \\
(3) \\
\text { GMM } \\
\end{array}$} & \multirow[b]{2}{*}{$\begin{array}{c}\text { Currency } \\
\text { Union or } \\
\text { Currency } \\
\text { Board } \\
(3) \\
\text { GMM }\end{array}$} \\
\hline & & & $\begin{array}{l}\text { Currency } \\
\text { Union or } \\
\text { Currency } \\
\text { Board } \\
(1) \\
\text { GMM }\end{array}$ & $\begin{array}{c}\text { Log } \\
\text { Differentiated } \\
\text { Product Trade } \\
\text { (2) } \\
\text { OLS } \\
\end{array}$ & $\begin{array}{c}\text { Log } \\
\text { Differentiated } \\
\text { Product Trade } \\
(2) \\
\text { GMM }\end{array}$ & $\begin{array}{l}\text { Currency } \\
\text { Union or } \\
\text { Currency } \\
\text { Board } \\
(2) \\
\text { GMM }\end{array}$ & & & \\
\hline Right Hand Side Variable & & & & & & & & & \\
\hline Currency Union/Board & $\begin{array}{c}1.246 \\
(0.206)\end{array}$ & $\begin{array}{c}0.219 \\
(0.214)\end{array}$ & & $\begin{array}{c}1.282 \\
(0.230)\end{array}$ & $\begin{array}{c}0.185 \\
(0.212)\end{array}$ & & $\begin{array}{c}0.423 \\
(0.169)\end{array}$ & $\begin{array}{c}0.094 \\
(0.201)\end{array}$ & \\
\hline Log Total Trade & & & $\begin{array}{c}2.35 \mathrm{E}-03 \\
(5.51 \mathrm{E}-04)\end{array}$ & & & $\begin{array}{l}2.51 \mathrm{E}-03 \\
(5.53 \mathrm{E}-04)\end{array}$ & & & $\begin{array}{c}1.29 \mathrm{E}-03 \\
(7.51 \mathrm{E}-04)\end{array}$ \\
\hline Log Export Price Level & $\begin{array}{c}1.877 \\
(0.108)\end{array}$ & $\begin{array}{l}1.879 \\
(0.108)\end{array}$ & $\begin{array}{l}-2.07 \mathrm{E}-03 \\
(3.68 \mathrm{E}-03)\end{array}$ & $\begin{array}{c}2.280 \\
(0.121)\end{array}$ & $\begin{array}{c}2.282 \\
(0.121)\end{array}$ & $\begin{array}{l}-1.81 E-03 \\
(4.33 E-03)\end{array}$ & $\begin{array}{c}2.267 \\
(0.102)\end{array}$ & $\begin{array}{c}2.268 \\
(0.102)\end{array}$ & $\begin{array}{c}1.47 \mathrm{E}-03 \\
(4.06 \mathrm{E}-03)\end{array}$ \\
\hline Log Product Real GDP & & & & $x$ & $x$ & $x$ & $x$ & $x$ & $x$ \\
\hline Log Product Real GDP/capita & & & & $x$ & $x$ & $\mathrm{X}$ & $X$ & $\mathrm{X}$ & $X$ \\
\hline Log Exporters' Real GDP & & & & $x$ & $x$ & $x$ & $x$ & $x$ & $X$ \\
\hline Log Exporters' real GDP/capita & & & & $x$ & $x$ & $x$ & $x$ & $x$ & $x$ \\
\hline Log Distance & & & & & & & $x$ & $\mathrm{x}$ & $x$ \\
\hline Preferential Trade Agreement & & & & & & & $x$ & $x$ & $x$ \\
\hline Common Language & & & & & & & $X$ & $x$ & $X$ \\
\hline Common Land Border & & & & & & & $x$ & $x$ & $x$ \\
\hline Exporter Fixed Effects & $x$ & $x$ & $x$ & $x$ & $x$ & $x$ & $x$ & $x$ & $x$ \\
\hline Importer Fixed Effects & $x$ & $x$ & $x$ & $x$ & $x$ & $x$ & $x$ & $x$ & $x$ \\
\hline Year Fixed Effects & $x$ & $x$ & $x$ & $x$ & $x$ & $x$ & $x$ & $x$ & $x$ \\
\hline Observations & 48808 & 48808 & 48808 & 48808 & 48808 & 48808 & 48808 & 48808 & 48808 \\
\hline
\end{tabular}

Notes: Each variable has been differenced as follows: From log differentiated product imports of country I from country E we have subtracted log differentiated product imports of country I from the US. The reason, derived in the model, is to eliminate country I specific effects. All variables are equivalently differenced. Standard errors corrected for heteroscedasticity and autocorrelation are reported in parenthesis. 
Table 3: Fixed Exchange Rate Regimes and Trade

\begin{tabular}{|c|c|c|c|c|c|c|c|c|c|}
\hline \multirow{4}{*}{$\begin{array}{l}\text { Exchange Rate Regime Data } \\
\text { Estimation Technique }\end{array}$} & \multirow{4}{*}{$\begin{array}{c}\text { Log } \\
\text { Differentiated } \\
\text { Product Trade } \\
\text { IMF } \\
\text { OLS }\end{array}$} & \multirow{4}{*}{$\begin{array}{l}\text { Log } \\
\text { Differentiated } \\
\text { e Product Trade } \\
\text { IMF } \\
\text { GMM }\end{array}$} & \multicolumn{6}{|c|}{ Left Hand Side Variable } & \multirow{4}{*}{$\begin{array}{c}\text { Fixed } \\
\text { Exchange } \\
\text { Rate } \\
\text { LYS } \\
\text { GMM }\end{array}$} \\
\hline & & & \multirow{3}{*}{$\begin{array}{c}\text { Fixed } \\
\text { Exchange } \\
\text { Rate } \\
\text { IMF } \\
\text { GMM } \\
\end{array}$} & \multirow{3}{*}{$\begin{array}{c}\text { Log } \\
\text { Differentiated } \\
\text { Product Trade } \\
\text { RogoffDF } \\
\text { OLS } \\
\end{array}$} & \multirow{3}{*}{$\begin{array}{c}\text { Log } \\
\text { Differentiated } \\
\text { Product Trade } \\
\text { RogoffDF } \\
\text { GMM } \\
\end{array}$} & \multirow{3}{*}{$\begin{array}{l}\text { Fixed } \\
\text { Exchange } \\
\text { Rate } \\
\text { RogoffDF } \\
\text { GMM } \\
\end{array}$} & \multirow{3}{*}{$\begin{array}{c}\text { Log } \\
\text { Differentiated } \\
\text { Product Trade } \\
\text { LYS } \\
\text { OLS } \\
\end{array}$} & \multirow{3}{*}{$\begin{array}{c}\text { Log } \\
\text { Differentiated } \\
\text { Product Trade } \\
\text { LYS } \\
\text { GMM } \\
\end{array}$} & \\
\hline & & & & & & & & & \\
\hline & & & & & & & & & \\
\hline Right Hand Side Variable & & & & & & & & & \\
\hline Fixed Exchange Rate & $\begin{array}{c}0.017 \\
(0.022)\end{array}$ & $\begin{array}{l}-0.037 \\
(0.026)\end{array}$ & & $\begin{array}{l}-0.002 \\
(0.023)\end{array}$ & $\begin{array}{c}0.064 \\
(0.031)\end{array}$ & & $\begin{array}{c}0.114 \\
(0.015)\end{array}$ & $\begin{array}{c}0.069 \\
(0.019)\end{array}$ & \\
\hline Log Total Trade & & & $\begin{array}{c}1.35 \mathrm{E}-02 \\
(4.59 \mathrm{E}-03)\end{array}$ & & & $\begin{array}{l}-6.68 \mathrm{E}-03 \\
-(2.65 \mathrm{E}-03)\end{array}$ & & & $\begin{array}{c}1.65 \mathrm{E}-02 \\
(4.69 \mathrm{E}-03)\end{array}$ \\
\hline Log Export Price Level & $\begin{array}{c}-0.648 \\
(0.061)\end{array}$ & $\begin{array}{l}-0.649 \\
(0.061)\end{array}$ & $\begin{array}{c}-0.012 \\
(0.019)\end{array}$ & $\begin{array}{c}-0.751 \\
(0.063)\end{array}$ & $\begin{array}{l}-0.750 \\
(0.063)\end{array}$ & $\begin{array}{l}-0.013 \\
(0.007)\end{array}$ & $\begin{array}{c}-0.747 \\
(0.063)\end{array}$ & $\begin{array}{c}-0.734 \\
(0.063)\end{array}$ & $\begin{array}{c}0.300 \\
(0.021)\end{array}$ \\
\hline Log Product Real GDP & $x$ & $x$ & $x$ & $x$ & $x$ & $x$ & $x$ & $x$ & $x$ \\
\hline Log Product Real GDP/capita & $x$ & $x$ & $x$ & $x$ & $x$ & $x$ & $x$ & $x$ & $x$ \\
\hline Log Exporters' Real GDP & $x$ & $x$ & $x$ & $x$ & $x$ & $x$ & $x$ & $x$ & $x$ \\
\hline Log Exporters' real GDP/capita & $x$ & $x$ & $x$ & $x$ & $x$ & $x$ & $x$ & $x$ & $x$ \\
\hline Preferential Trade Agreement & $x$ & $x$ & $x$ & $x$ & $x$ & $x$ & $x$ & $x$ & $x$ \\
\hline Importer-Exporter Fixed Effects & $x$ & $x$ & $x$ & $x$ & $x$ & $x$ & $x$ & $x$ & $x$ \\
\hline Year Fixed Effects & $x$ & $x$ & $x$ & $x$ & $x$ & $x$ & $x$ & $x$ & $x$ \\
\hline Observations & 45061 & 45061 & 45061 & 48791 & 48791 & 48791 & 45568 & 45568 & 45568 \\
\hline
\end{tabular}

Notes: Each variable has been differenced as follows: From log differentiated product imports of country I from country E we have subtracted log differentiated product imports of country I from the US. The reason, derived in the model, is to eliminate country I specific effects. All variables are equivalently differenced. Standard errors corrected for heteroscedasticity and autocorrelation are reported in parenthesis. 
Table 4: Sensitivity to Different Volatility Measures

\begin{tabular}{|c|c|c|c|c|c|c|c|c|c|c|c|c|}
\hline \multirow[b]{2}{*}{$\begin{array}{l}\text { Exchange Volatility Measure } \\
\text { Estimation Technique }\end{array}$} & \multicolumn{12}{|c|}{ Left Hand Side Variable } \\
\hline & $\begin{array}{c}\text { Log } \\
\text { Differentiated } \\
\text { Product Trade } \\
\text { Long } \\
\text { OLS } \\
\end{array}$ & $\begin{array}{c}\text { Log Real } \\
\text { Exchange } \\
\text { Rate Volatility } \\
\text { Long } \\
\text { OLS } \\
\end{array}$ & $\begin{array}{c}\text { Log } \\
\text { Differentiated } \\
\text { Product Trade } \\
\text { Long } \\
\text { GMM } \\
\end{array}$ & $\begin{array}{c}\text { Log Real } \\
\text { Exchange } \\
\text { Rate Volatility } \\
\text { Long } \\
\text { GMM } \\
\end{array}$ & $\begin{array}{c}\text { Log } \\
\text { Differentiated } \\
\text { Product Trade } \\
\text { Medium } \\
\text { OLS } \\
\end{array}$ & $\begin{array}{l}\text { Log Real } \\
\text { Exchange } \\
\text { Rate Volatility } \\
\text { Medium } \\
\text { OLS } \\
\end{array}$ & $\begin{array}{c}\text { Log } \\
\text { Differentiated } \\
\text { Product Trade } \\
\text { Medium } \\
\text { GMM } \\
\end{array}$ & $\begin{array}{c}\text { Log Real } \\
\text { Exchange } \\
\text { Rate Volatility } \\
\text { Medium } \\
\text { GMM } \\
\end{array}$ & $\begin{array}{c}\text { Log } \\
\text { Differentiated } \\
\text { Product Trade } \\
\text { Short } \\
\text { OLS } \\
\end{array}$ & $\begin{array}{c}\text { Log Real } \\
\text { Exchange } \\
\text { Rate Volatility } \\
\text { Short } \\
\text { OLS } \\
\end{array}$ & $\begin{array}{c}\text { Log } \\
\text { Differentiated } \\
\text { Product Trade } \\
\text { Short } \\
\text { GMM } \\
\end{array}$ & $\begin{array}{c}\text { Log Real } \\
\text { Exchange } \\
\text { Rate Volatility } \\
\text { Short } \\
\text { GMM } \\
\end{array}$ \\
\hline Right Hand Side Variable & & & & & & & & & & & & \\
\hline Log Real Exchange Rate Volatility & $\begin{array}{l}-0.016 \\
(0.006)\end{array}$ & & $\begin{array}{l}-0.011 \\
(0.008)\end{array}$ & & $\begin{array}{l}-0.027 \\
(0.009)\end{array}$ & & $\begin{array}{l}-0.001 \\
(0.001)\end{array}$ & & $\begin{array}{l}-0.134 \\
(0.015)\end{array}$ & & $\begin{array}{l}-0.071 \\
(0.020)\end{array}$ & \\
\hline Log Total Trade & & $\begin{array}{l}-0.014 \\
(0.008)\end{array}$ & & $\begin{array}{c}-0.012 \\
(0.014)\end{array}$ & & $\begin{array}{c}-0.014 \\
(0.006)\end{array}$ & & $\begin{array}{c}-0.032 \\
(0.010)\end{array}$ & & $\begin{array}{l}-0.039 \\
(0.005)\end{array}$ & & $\begin{array}{l}-0.037 \\
(0.008)\end{array}$ \\
\hline Log Export Price Level & $\begin{array}{l}-0.700 \\
(0.064)\end{array}$ & $\begin{array}{c}0.079 \\
(0.044)\end{array}$ & $\begin{array}{l}-0.701 \\
(0.064)\end{array}$ & $\begin{array}{c}0.080 \\
(0.044)\end{array}$ & $\begin{array}{l}-0.699 \\
(0.064)\end{array}$ & $\begin{array}{c}0.097 \\
(0.032)\end{array}$ & $\begin{array}{l}-0.701 \\
(0.042)\end{array}$ & $\begin{array}{c}0.092 \\
(0.032)\end{array}$ & $\begin{array}{l}-0.711 \\
(0.064)\end{array}$ & $\begin{array}{l}-0.086 \\
(0.027)\end{array}$ & $\begin{array}{l}-0.707 \\
(0.064)\end{array}$ & $\begin{array}{l}-0.071 \\
(0.020)\end{array}$ \\
\hline Log Product Real GDP & $\mathrm{x}$ & $\mathrm{x}$ & $\mathrm{x}$ & $\mathrm{x}$ & $\mathrm{x}$ & $\mathrm{x}$ & $\mathrm{x}$ & $\mathrm{x}$ & $\mathrm{x}$ & $\mathrm{x}$ & $\mathrm{x}$ & $\mathrm{x}$ \\
\hline Log Product Real GDP/capita & $x$ & $x$ & $x$ & $x$ & $x$ & $x$ & $x$ & $x$ & $x$ & $x$ & $x$ & $x$ \\
\hline Log Exporters' Real GDP & $x$ & $\mathrm{x}$ & $x$ & $\mathrm{x}$ & $x$ & $\mathrm{x}$ & $x$ & $x$ & $\mathrm{x}$ & $x$ & $x$ & $x$ \\
\hline Log Exporters' real GDP/capita & $\mathrm{x}$ & $\mathrm{x}$ & $x$ & $x$ & $\mathrm{x}$ & $\mathrm{x}$ & $\mathrm{x}$ & $\mathrm{x}$ & $x$ & $\mathrm{x}$ & $\mathrm{x}$ & $x$ \\
\hline Importer-Exporter Fixed Effects & $\mathrm{x}$ & $\mathrm{x}$ & $\mathrm{x}$ & $\mathrm{x}$ & $\mathrm{x}$ & $\mathrm{x}$ & $\mathrm{x}$ & $x$ & $\mathrm{x}$ & $\mathrm{x}$ & $\mathrm{x}$ & $x$ \\
\hline Year Fixed Effects & $x$ & $\mathrm{x}$ & $x$ & $\mathrm{x}$ & $\mathrm{x}$ & $\mathrm{x}$ & $\mathrm{x}$ & $x$ & $\mathrm{x}$ & $\mathrm{x}$ & $\mathrm{x}$ & $\mathrm{x}$ \\
\hline Observations & 47521 & 47521 & 47521 & 47521 & 47521 & 47521 & 47521 & 47521 & 47521 & 47521 & 47521 & 47521 \\
\hline
\end{tabular}

Notes: Each variable has been differenced as follows: From log differentiated product imports of country I from country E we have subtracted log differentiated product imports of country I from the US. The reason, derived in the model, is to eliminate country I specific effects. All variables are equivalently differenced.

Standard errors corrected for heteroscedasticity and autocorrelation are reported in parenthesis. 
Table 5: Developing v Developed Country Exporters

\begin{tabular}{|c|c|c|c|c|c|c|c|c|}
\hline \multirow[b]{2}{*}{$\begin{array}{l}\text { Exporter } \\
\text { Estimation Technique }\end{array}$} & \multirow[b]{2}{*}{$\begin{array}{c}\text { Log } \\
\text { Differentiated } \\
\text { Product Trade } \\
\text { Developing } \\
\text { GMM }\end{array}$} & \multirow[b]{2}{*}{$\begin{array}{l}\text { Log Real } \\
\text { Exchange } \\
\text { Rate Volatility } \\
\text { Developing } \\
\text { GMM } \\
\end{array}$} & \multirow[b]{2}{*}{$\begin{array}{c}\text { Log } \\
\text { Differentiated } \\
\text { Product Trade } \\
\text { Developing } \\
\text { GMM }\end{array}$} & \multicolumn{3}{|c|}{ Left Hand Side Variable } & \multirow[b]{2}{*}{$\begin{array}{c}\text { Log } \\
\text { Differentiated } \\
\text { Product Trade } \\
\text { Developed } \\
\text { GMM }\end{array}$} & \multirow[b]{2}{*}{$\begin{array}{l}\text { Log Real } \\
\text { Exchange } \\
\text { Rate Volatility } \\
\text { Developed } \\
\text { GMM }\end{array}$} \\
\hline & & & & $\begin{array}{c}\text { Log Real } \\
\text { Exchange } \\
\text { Rate Volatility } \\
\text { Developing } \\
\text { GMM }\end{array}$ & $\begin{array}{c}\text { Log } \\
\text { Differentiated } \\
\text { Product Trade } \\
\text { Developed } \\
\text { GMM } \\
\end{array}$ & $\begin{array}{c}\text { Log Real } \\
\text { Exchange } \\
\text { Rate Volatility } \\
\text { Developed } \\
\text { GMM }\end{array}$ & & \\
\hline Right Hand Side Variable & & & & & & & & \\
\hline Log Real Exchange Rate Volatility & $\begin{array}{l}-0.053 \\
(0.019)\end{array}$ & & $\begin{array}{l}-0.037 \\
(0.019)\end{array}$ & & $\begin{array}{c}0.036 \\
(0.020)\end{array}$ & & $\begin{array}{c}0.071 \\
(0.020)\end{array}$ & \\
\hline Log Total Trade & & $\begin{array}{l}-0.028 \\
(0.009)\end{array}$ & & $\begin{array}{l}-0.020 \\
(0.009)\end{array}$ & & $\begin{array}{l}-0.042 \\
(0.028)\end{array}$ & & $\begin{array}{l}-0.088 \\
(0.029)\end{array}$ \\
\hline Log Export Price Level & $\begin{array}{l}-0.615 \\
(0.070)\end{array}$ & $\begin{array}{l}-0.101 \\
(0.030)\end{array}$ & $\begin{array}{l}-0.884 \\
(0.080)\end{array}$ & $\begin{array}{c}0.109 \\
(0.031)\end{array}$ & $\begin{array}{l}-0.496 \\
(0.072)\end{array}$ & $\begin{array}{l}-0.057 \\
(0.068)\end{array}$ & $\begin{array}{c}0.218 \\
(0.095)\end{array}$ & $\begin{array}{c}0.109 \\
(0.087)\end{array}$ \\
\hline Log Product Real GDP & & & $X$ & $x$ & & & $X$ & $X$ \\
\hline Log Product Real GDP/capita & & & $x$ & $X$ & & & $x$ & $x$ \\
\hline Log Exporters' Real GDP & & & $x$ & $\mathrm{X}$ & & & $x$ & $x$ \\
\hline Log Exporters' real GDP/capita & & & $\mathrm{X}$ & $x$ & & & $\mathrm{X}$ & $\mathrm{X}$ \\
\hline Importer-Exporter Fixed Effects & $\mathrm{X}$ & $X$ & $X$ & $X$ & $x$ & $\mathrm{X}$ & $X$ & $X$ \\
\hline Year Fixed Effects & $x$ & $\mathrm{X}$ & $\mathrm{X}$ & $x$ & $x$ & $x$ & $\mathrm{X}$ & $\mathrm{X}$ \\
\hline Observations & 27481 & 27481 & 27481 & 27481 & 20040 & 20040 & 20040 & 20040 \\
\hline
\end{tabular}

Notes: Each variable has been differenced as follows: From log differentiated product imports of country I from country E we have subtracted log differentiated product imports of country I from the US. The reason, derived in the model, is to eliminate country I specific effects. All variables are equivalently differenced.

Standard errors corrected for heteroscedasticity and autocorrelation are reported in parenthesis. 
Table 6: Robustness to Inclusion of Capital Controls and Capital Flows

\begin{tabular}{|c|c|c|c|c|c|c|c|c|c|c|c|c|c|}
\hline & \multicolumn{13}{|c|}{ Left Hand Side Variable } \\
\hline & $\begin{array}{c}\text { Log } \\
\text { Differentiated } \\
\text { Product Trade } \\
\text { Volatility } \\
\text { OLS } \\
\end{array}$ & $\begin{array}{l}\text { Log Real } \\
\text { Exchange } \\
\text { Rate Volatility } \\
\text { Volatility } \\
\text { OLS }\end{array}$ & $\begin{array}{c}\text { Log } \\
\text { Differentiated } \\
\text { Product Trade } \\
\text { Volatility } \\
\text { GMM } \\
\end{array}$ & $\begin{array}{c}\text { Log Real } \\
\text { Exchange } \\
\text { Rate Volatility } \\
\text { Volatility } \\
\text { GMM }\end{array}$ & $\begin{array}{c}\text { Log } \\
\text { Differentiated } \\
\text { Product Trade } \\
\text { CU } \\
\text { OLS } \\
\end{array}$ & $\begin{array}{c}\text { Log } \\
\text { Differentiated } \\
\text { Product Trade } \\
\text { CU } \\
\text { GMM } \\
\end{array}$ & $\begin{array}{c}\text { Currency } \\
\text { Union or } \\
\text { Currency } \\
\text { Board } \\
\text { CU } \\
\text { GMM }\end{array}$ & $\begin{array}{c}\text { Log } \\
\text { Differentiated } \\
\text { Product Trade } \\
\text { RogoffDF } \\
\text { OLS } \\
\end{array}$ & $\begin{array}{l}\text { Log } \\
\text { Differentiated } \\
\text { Product Trade } \\
\text { RogoffDF } \\
\text { GMM }\end{array}$ & $\begin{array}{c}\text { Currency } \\
\text { Union or } \\
\text { Currency } \\
\text { Board } \\
\text { RogoffDF } \\
\text { GMM }\end{array}$ & $\begin{array}{l}\text { Log } \\
\text { Differentiated } \\
\text { Product Trade } \\
\text { LYS } \\
\text { OLS } \\
\end{array}$ & $\begin{array}{l}\text { Log } \\
\text { Differentiated } \\
\text { Product Trade } \\
\text { LYS } \\
\text { GMM } \\
\end{array}$ & $\begin{array}{c}\text { Currency } \\
\text { Union or } \\
\text { Currency } \\
\text { Board } \\
\text { LYS } \\
\text { GMM }\end{array}$ \\
\hline Right Hand Side Variable & & & & & & & & & & & & & \\
\hline Log Real Exchange Rate Volatility & $\begin{array}{c}-0.040 \\
(0.013)\end{array}$ & & $\begin{array}{c}0.008 \\
(0.016)\end{array}$ & & & & & & & & & & \\
\hline Currency Union/Board & & & & & $\begin{array}{c}0.356 \\
(0.173)\end{array}$ & $\begin{array}{c}0.080 \\
(0.212)\end{array}$ & & & & & & & \\
\hline Fixed Exchange Rate & & & & & & & & $\begin{array}{c}0.021 \\
(0.023)\end{array}$ & $\begin{array}{c}0.061 \\
(0.032)\end{array}$ & & $\begin{array}{c}0.109 \\
(0.016)\end{array}$ & $\begin{array}{c}0.051 \\
(0.019)\end{array}$ & \\
\hline Log Total Trade & & $\begin{array}{l}-0.020 \\
(0.005)\end{array}$ & & $\begin{array}{l}-0.037 \\
(0.009)\end{array}$ & & & $\begin{array}{c}1.20 \mathrm{E}-03 \\
(8.63 \mathrm{E}-04)\end{array}$ & & & $\begin{array}{c}-4.39 \mathrm{E}-03 \\
(2.83 \mathrm{E}-03)\end{array}$ & & & $\begin{array}{c}2.21 \mathrm{E}-02 \\
(5.00 \mathrm{E}-03)\end{array}$ \\
\hline Log Export Price Level & $\begin{array}{l}-0.581 \\
(0.066)\end{array}$ & $\begin{array}{l}-0.002 \\
(0.030)\end{array}$ & $\begin{array}{l}-0.582 \\
(0.066)\end{array}$ & $\begin{array}{c}0.008 \\
(0.016)\end{array}$ & $\begin{array}{c}2.174 \\
(0.109)\end{array}$ & $\begin{array}{c}2.174 \\
(0.109)\end{array}$ & $\begin{array}{c}6.00 \mathrm{E}-06 \\
(4.68 \mathrm{E}-03)\end{array}$ & $\begin{array}{l}-0.623 \\
(0.064)\end{array}$ & $\begin{array}{l}-0.622 \\
(0.064)\end{array}$ & $\begin{array}{l}-3.26 \mathrm{E}-02 \\
(7.14 \mathrm{E}-03)\end{array}$ & $\begin{array}{l}-0.704 \\
(0.065)\end{array}$ & $\begin{array}{l}-0.688 \\
(0.065)\end{array}$ & $\begin{array}{c}2.83 \mathrm{E}-01 \\
(2.24 \mathrm{E}-02)\end{array}$ \\
\hline Log Product Real GDP & $\mathrm{x}$ & $\mathrm{x}$ & $x$ & $\mathrm{x}$ & $\mathrm{x}$ & $\mathrm{x}$ & $\mathrm{x}$ & $\mathrm{x}$ & $\mathrm{x}$ & $\mathrm{x}$ & $\mathrm{x}$ & $\mathrm{x}$ & $\mathrm{x}$ \\
\hline Log Product Real GDP/capita & $x$ & $\mathrm{x}$ & $\mathrm{x}$ & $\mathrm{x}$ & $\mathrm{x}$ & $\mathrm{x}$ & $\mathrm{x}$ & $\mathrm{x}$ & $x$ & $x$ & $x$ & $x$ & $x$ \\
\hline Log Exporters' Real GDP & $\mathrm{x}$ & $\mathrm{x}$ & $\mathrm{x}$ & $\mathrm{x}$ & $\mathrm{x}$ & $\mathrm{x}$ & $\mathrm{x}$ & $\mathrm{x}$ & $\mathrm{x}$ & $\mathrm{x}$ & $\mathrm{x}$ & $\mathrm{x}$ & $\mathrm{x}$ \\
\hline Log Exporters' real GDP/capita & $\mathrm{x}$ & $\mathrm{x}$ & $\mathrm{x}$ & $\mathrm{x}$ & $\mathrm{x}$ & $\mathrm{x}$ & $\mathrm{x}$ & $\mathrm{x}$ & $\mathrm{x}$ & $\mathrm{x}$ & $\mathrm{x}$ & $\mathrm{x}$ & $\mathrm{x}$ \\
\hline Log Distance & & & & & $\mathrm{x}$ & $x$ & $x$ & & & & & & \\
\hline Preferential Trade Agreement & & & & & $\mathrm{x}$ & $\mathrm{x}$ & $x$ & & & & & & \\
\hline Common Language & & & & & $\mathrm{x}$ & $\mathrm{x}$ & $\mathrm{x}$ & & & & & & \\
\hline Common Land Border & & & & & $x$ & $\mathrm{x}$ & $x$ & & & & & & \\
\hline Gross Private Capital Flows & $\mathrm{x}$ & $\mathrm{x}$ & $\mathrm{x}$ & $\mathrm{x}$ & $x$ & $x$ & $x$ & $\mathrm{x}$ & $\mathrm{x}$ & $\mathrm{x}$ & $\mathrm{x}$ & $\mathrm{x}$ & $\mathrm{x}$ \\
\hline Capital Controls & $x$ & $\mathrm{x}$ & $x$ & $x$ & $\mathrm{x}$ & $x$ & $x$ & $x$ & $x$ & $\mathrm{x}$ & $x$ & $x$ & $x$ \\
\hline Importer-Exporter Fixed Effects & $\mathrm{x}$ & $x$ & $x$ & $\mathrm{x}$ & & & & $x$ & $x$ & $x$ & $x$ & $x$ & $\mathrm{x}$ \\
\hline Exporter Fixed Effects & & & & & $x$ & $x$ & $x$ & & & & & & \\
\hline Importer Fixed Effects & & & & & $\mathrm{x}$ & $\mathrm{x}$ & $x$ & & & & & & \\
\hline Year Fixed Effects & $x$ & $x$ & $x$ & $x$ & $x$ & $x$ & $x$ & $x$ & $x$ & $x$ & $x$ & $x$ & $x$ \\
\hline Observations & 39979 & 39979 & 39979 & 39979 & 41265 & 41265 & 41265 & 41258 & 41258 & 41258 & 40304 & 40304 & 40304 \\
\hline
\end{tabular}

Notes: Each variable has been differenced as follows: From log differentiated product imports of country I from country E we have subtracted log differentiated product imports of country I from the US. The reason, derived in the model, is to eliminate country I specific effects. All variables are equivalently differenced. Standard errors corrected for heteroscedasticity and autocorrelation are reported in parenthesis. 